\title{
Türkiye ormancılığı için alternatif örgütlenme modellerinin geliştirilmesi
}

\author{
Murat KÖSE (Orcid: 0000-0001-5891-5164) ${ }^{1}$, İsmet DAŞDEMİR (Orcid: 0000-0002-3170-644X)²*, \\ Seçil YURDAKUL EROL (Orcid: 0000-0003-4495-1118) ${ }^{3}$, Hasan Tezcan YILDIRIM (Orcid: 0000-0002-8180-0557) \\ Avni ARSLAN (Orcid: 0000-0001-8486-9667) ${ }^{4}$, Emre GÖKSU (Orcid: 0000-0002-1205-5872), \\ Umut Ahmet ŞEKERCAN (Orcid: 0000-0002-5748-4742) ${ }^{6}$, Süleyman ALKAN (Orcid: 0000-0001-8310-0047) ${ }^{7}$
}

${ }^{1}$ Marmara Ormancılık Araştırma Enstitüsü Müdürlüğü, İstanbul

${ }^{2}$ Bartın Üniversitesi Orman Fakültesi, Bartın

${ }^{3}$ İstanbul Üniversitesi Cerrahpaşa, Orman Fakültesi, İstanbul

${ }^{4}$ Batı Karadeniz Ormancılık Araştırma Enstitüsü Müdürlüğ̈̈, Bolu

${ }^{5}$ Ege Ormanc1lık Araştırma Enstitüsü Müdürlüğü, İzmir

${ }^{6}$ Orman Genel Müdürlüğü, Odun Dışı Orman Ürünleri ve Hizmetleri Dairesi Başkanlığı, Ankara

${ }^{7}$ Batı Akdeniz Ormancılık Araştırma Enstitüsü Müdürlüğü, Antalya

*Sorumlu yazar/Corresponding author: isdasdemir@hotmail.com Geliş tarihi/Received: 27.06.2018 Kabul Tarihi/Accepted: 09.07.2018

$\ddot{O} \mathbf{z}$

Bu çalışma, Türkiye'deki ormancılık örgütünün mevcut durumunu, yönetim ve organizasyon sorunlarını ortaya koymak, alternatif örgütlenme modellerini geliştirmek ve en uygun olanını belirlemek amacıyla yapılmıştır. Araştırma verilerini toplamak için Orman ve Su İşleri Bakanlığına bağlı ormancılık birimleri kapsamında, Türkiye'de dokuz bölgede, dört farklı ilgi grubundan (çalışanlar, uzmanlar, ilgili kurum ve STK temsilcileri) toplam 565 deneğe dört farklı anket yüz yüze görüşme tekniği ile uygulanmış, ilgi gruplarıyla görüşmeler yapılmış ve toplantılar düzenlenmiştir. Denekler, katmanl1-basit rastgele örnekleme yöntemine göre belirlenmiştir. Araştırmanın temel materyalini anket uygulamasından ve görüşmelerden elde edilen veriler oluşturmaktadır. Veriler betimsel istatistiklerle değerlendirilmiş, ormanc1lı örgütünün yönetimi ve örgütlenmesi ile ilgili düşüncelerin bölgelere, birimlere, göreve ve deneyime göre farklılığı Kruskal-Wallis H-Testi ile denetlenmiş ve farklı gruplar Duncan Testi ile belirlenmiştir. Araştırma kapsamında Türkiye'deki ormancılık örgütünün mevcut durumu saptanmış, yönetim ve organizasyon sorunları ortaya konmuştur. Türkiye ormancıllğı için alternatif örgütlenme ve yönetim modelleri geliştirilmiş ve dört ilgi grubu tarafından en fazla tercih edilen modellerin "Model-3" ve "Model-2" olduğu saptanmıştır. Model3’te, ormancılık örgütü merkezde altı ayrı genel müdürlük, taşrada ise homojen havzalarda bölgesel Ormanc1lık Araştırma-Geliştirme ve Denetleme birimleri ile mikro havzalar bazında güçlü tek bir ormancılık işletmesi şeklinde yapılandırılmaktadır. Model-2'de, ormancılık örgütünün merkezde Orman Genel Müdürlüğü, taşrada ise havza bazında bölgesel ve işletme şeklinde tek birim olarak örgütlenmesi ve yönetilmesi esastır. Her iki modelde de orman kaynaklarının bir bütünlük anlayışı içerisinde yönetilmesine, yetki-sorumluluk çatışmasının ortadan kalkmasına, kaynakların etkin kullanılmasına, örgütün dinamik bir yapıya kavuşmasına, personelin tavandan tabana yayılmasına hizmet etmektedir. Modeller tartışılarak öneriler geliştirilmiş, karar vericilerin ve uygulayıcıların değerlendirmesine sunulmuştur.

Anahtar Kelimeler: Ormanc1lık yönetimi ve örgütlenmesi, örgüt yapısı modeli, Orman ve Su İşleri Bakanlığı, Türkiye.

\section{Development of alternative organizational models for forestry in Turkey}

\begin{abstract}
This study aimed at defining the current situation of forestry organization, the management and organization problems in Turkey, to develop alternative organizational models and to determine the most appropriate. To collect data, four different questionnaires were applied face to face to the 565 subjects from four different interest groups (employees, experts, relevant institutions and NGO representatives), and meetings were held with the forestry units under the Ministry of Forestry and Water Affairs in nine regions in Turkey. The interviewees were determined according to the stratified-simple random sampling method. The basic material of this study is the data obtained from the survey and interviews. Data were evaluated with descriptive statistics, the differences of opinions regarding the management and organization of the forestry according to the regions, the units, the task, and the experience were inspected by the Kruskal-Wallis H-Test and the different groups were determined via the Duncan Test. Within the scope of the research, the current situation of forestry organization in Turkey was determined, and the management and organizational problems were presented. The alternative organization and management models for forestry in Turkey were developed and it was determined that the most preferred models by four different interest groups were "Model-3" and
\end{abstract}

To cite this article (Atıf): KÖSE, M , DAŞDEMİ, İ, YURDAKUL EROL, S, YILDIRIM, H, ARSLAN, A, GÖKSU, E, ŞEKERCAN, U, ALKAN, S . (2018). Türkiye ormancılığı için alternatif örgütlenme modellerinin geliștirilmesi. Ormancılık Araştırma Dergisi, 5 (2), $143-168$. DOI: $10.17568 /$ ogmoad.437335 
"Model-2". In Model-3, the forestry organization is structured as six separate general directorates in the center, and only one strong forest district directorate on the basis of micro-basins with Regional Forestry Research-Development and Supervision units in homogeneous basins in the provinces. In Model-2, a centralized forestry organization is essential in organizing and managing from the head office, and in the regions, there are directorates and sub-district units on the basin basis as a single unit. Both models serve to manage the forest resources in a sense of integrity by resolving the conflict of authority-responsibility, to utilize resources effectively, to attain the organization a dynamic structure and to spread the staff from the top to the bottom. Proposals were developed by discussing the models and presented to the decision-makers and practitioners for consideration.

Keywords: Forestry management and organization, organization structure model, Ministry of Forestry and Water Affairs, Turkey

\section{Giriș}

Yönetim olgusu insanlık tarihi kadar eskidir. Aile birimi temelinde başlayan yönetim, ilkel toplumlardan günümüzdeki modern işletmelere kadar gereksinim duyulan bir süreçtir. İki ya da daha fazla insanın bir plan eşliğinde, eşgüdüm içerisinde yaptıkları faaliyet olarak tanımlanan yönetimin işlevlerinden biri de örgütlenmedir. Örgütlenme kişiler ile her türlü fiziksel varlıkların kuruluşun amacını gerçekleştirecek biçimde düzenlenmesidir. Örgüt ise bu süreç sonunda oluşan, belirli yapı, kural ve süreçler bütünüdür (Özdönmez ve ark., 1998). Dolayısıyla örgüt, yönetim etkinliklerinin içinde gerçekleştiği bir ortam ve belirlenen kurumsal amaçlara ulaşmak için kullanılan bir araçtır.

Yönetimin başarılı olması için iyi bir örgütlenmeye ve örgüt yapısına ihtiyaç vardır. Keza örgütün başarılı olabilmesi için yönetici olacak kişilerin belirli özelliklere sahip olması ve yetki ve sorumluluklarının farkında olması gerekir (Gülen ve Özdönmez, 1996). Yönetim ve örgütlenmede siyasi kararların baskın olması, sık sık değişmesi ve objektif kriterlere dayalı personel politikasının olmaması çalışanların moral ve disiplinlerini zayıflatmakta ve örgütü başarısız kılmaktadır. İlkel toplumdan tarım toplumuna, tarım toplumundan sanayi toplumuna ve sanayi toplumundan sanayi ötesi topluma (bilgi toplumuna) geçişte vazgeçilmez ve tükenmez bir kaynak olan bilginin ve teknolojinin önemi çok büyüktür (Bensghir, 1996). Bu değişim ve gelişim, toplumsal ve ekonomik örgütlerin yanında kamu kuruluşlarını da değişmeye, gelişmeye, yeni durumlara adapte olmaya ve içinde bulunulan sektörün özelliğine göre çağdaş örgütlenme ve yönetim anlayışlarına zorlamaktadır.

\subsection{Türkiye ormancılık örgütünün tarihsel gelişimi}

Osmanlı İmparatorluğu, 1839 Tanzimat Fermanı'ndan sonra batılılaşma anlamında adımlar atmaya başlamıştır. Bu kapsamda 1839 yılında Ticaret Bakanlığına bağlı olarak İstanbul'da “Orman Müdürlüğü” adıyla ilk ormancılık örgütü kurulmuştur. Orman Müdürlüğüne bağlı olarak taşrada bazı şeflikler kurulmuş ve tayinler de yapılmıştır. Ancak kurulan Orman Müdürlüğü yaklaşık bir yıl yaşayabilmiştir (Kutluk, 1948; Bingöl, 1990; Eryılmaz, 1985; Daşdemir, 2016a). Ormancılık örgütünün ilk adımını oluşturan müdürlük kısa bir denemeden öteye gidememiştir.

Devlet, hazinenin gereksinim duyduğu geliri sağlamak için ormanları işletmek, faydalanmayı sürekli hale getirmek için de ormancılık tekniğini tam olarak uygulama gereğini duymuştur. Bu çerçevede 1856 yılında Fransa'dan uzmanlar getirtilmiştir (Eraslan, 1989). Bu devredeki ormancılık çalışmalarını yürüten heyetin başında bulunan Fransız Orman Uzmanı Louis Tassy, 1857-1862 ve 1865-1868 yılları arasında yaklaşık 8 yıl Türkiye'de kalmıştır. Tassy’ye başlıca; Orman Okulunun açılması, Orman Nizamnamesinin hazırlanmas1, ormanlarımızın keşfi ve Ormancılık Örgütünün kurulması görevleri verilmiştir (Yund, 1969). Tassy’nin gayretleriyle 1857 yılında Ticaret Bakanlığı bünyesinde İstanbul'da bir Orman Okulu kurulmuş (Kutluk, 1967) ve bu okulun müdürlüğü kendisine verilmiştir. Orman Okulunun kuruluş tarihi olan 1857 yılı birçok bilim adamı ve ormancı tarafından “Türkiye'de ormancılığın başlangıç tarihi” olarak değerlendirilmektedir (Kutluk,1967; Eraslan,1989). 1870 tarihinde çıkarılan Orman Nizamnamesi ile ormanlardan serbestçe yararlanmaların önüne geçilmeye çalışılmış, devlet ormanlarının imtiyaz yoluyla işletilmesi ve satışların dikili olarak yapılması öngörülmüştür. (Özdönmez ve ark., 1989; Daşdemir, 2016a).

Osmanlı döneminde Ticaret Bakanlığı bünyesi ile başlayan örgütlenme biçimi, İktisat Bakanlığı ile son bulmuştur (Tablo 1). Bu örgütlenme anlayışının tamamen ormanlardan gelir elde etme ihtiyacının şekillendirdiği bir model olduğu anlaşılmaktadır (Gümüş, 2014a). Cumhuriyet döneminde ise İktisat Bakanlığ 1 bünyesinde başlayan ormancılık örgütlenmesi ve yönetimi çalışmaları halen Orman ve Su İşleri Bakanlığı (OSİB) bünyesinde yürütülmektedir (Tablo 1). 
Tablo 1. Türkiye'de ormanc1lık örgütünün bağlı olduğu bakanlıklar ve y1llar

Table 1. Ministries that the forestry organization has been affiliated through the years in Turkey

\begin{tabular}{|c|c|c|c|}
\hline \multicolumn{2}{|c|}{ Cumhuriyet öncesi dönem } & \multicolumn{2}{|l|}{ Cumhuriyet dönemi } \\
\hline Bakanlıklar & Yillar & Bakanlıklar & Yillar \\
\hline Ticaret Bakanlığg1 & $1839-1869$ & İktisat Bakanlığ 1 & 1923-1924 \\
\hline Maliye Bakanlığg1 & $1869-1972$ & Tarım Bakanlığı & $1925-1928$ \\
\hline Orman ve Maden Bakanlığ1 & 1872 & İktisat Bakanlı̆̆1 & $1928-1931$ \\
\hline Maliye Bakanlığı & $1873-1877$ & Tarım Bakanllı̆ 1 & 1931-1969 \\
\hline Orman ve Maden Bakanlığı & 1878 & Orman Bakanlığg1 & 1969-1981 \\
\hline Ticaret ve Tarım Bakanlığı & $1879-1886$ & Tarım ve Orman Bakanlığg1 & $1981-1983$ \\
\hline Maliye Bakanlığ 1 & $1887-1892$ & Tarım, Orman ve Köyişleri Bakanlığı & $1983-1991$ \\
\hline Orman, Maden ve Tarım Bakanlığı & 1893-1908 & Orman Bakanlığ1 & $1991-2003$ \\
\hline Ticaret ve Tarım Bakanlığ & $1909-1920$ & Çevre ve Orman Bakanlığg1 & 2003-2011 \\
\hline İktisat Bakanlığ1 & $1920-1923$ & Çevre, Orman ve Şehircilik Bakanlığ 1 & 2011 (26 Gün) \\
\hline & & Orman ve Su İşleri Bakanlığı (OSİB) & 2011- \\
\hline
\end{tabular}

1937 yılında çıkarılan 3204 sayılı Kanunla hükmü şahsiyeti haiz katma bütçeli bir idare olarak Orman Genel Müdürlüğü (OGM) kurulmuştur. Aynı yıl yürürlüğe giren 3116 sayılı Orman Kanunu ile bilimsel ve teknik ormancılığın temelleri atılmıştır. OGM, 1937 yılından itibaren taşrada da teşkilatlanmasını sürdürerek, 1945 yılında devlet orman işletmeleri, 1951 yılından itibaren de orman başmüdürlükleri kurulmaya başlanmış ve devlet orman işletmeleri bu başmüdürlüklere bağlanmıştır. Daha sonra başmüdürlüklerin adı orman bölge müdürlükleri şeklinde değiştirilmiştir.

1937'den itibaren Tarım Bakanlığı'na bağlı OGM tarafından yürütülen ormancılık çalışmaları, 1969 yılında ilk defa Orman Bakanlığı'nın kurulmasıyla birlikte bakanlık seviyesinde yürütülmeye başlanmıştır. 1969-1981 yılları arasında Orman Bakanlığına bağlı OGM, Ağaçlandırma ve Erozyon Kontrolü Genel Müdürlüğü (AGM), Orman-Köy İlişkileri Genel Müdürlüğü (ORKÖY), Milli Parklar ve Avcılık Genel Müdürlüğü (MP) ve Orman Ürünleri Sanayi Genel Müdürlüğü (ORÜS) şeklinde beş genel müdürlük ve bu genel müdürlüklerin Bölge Müdürlükleri vasıtasıyla yürütülmüştür. 1981 yılında Orman Bakanlığ 1 ve Tarım Bakanlığ ile birleştirilerek, 1983 yılında da Tarım, Orman ve Köyişleri Bakanlığı kurularak, ormancılık hizmetleri 1991 yılına kadar bu bakanlığın bünyesinde yer alan OGM tarafından yürütülmüştür. 1991 yılında Orman Bakanlığı'nın yeniden kurulması ile beraber ormancilik hizmetleri merkezde bakanlığa bağlı dört genel müdürlük (OGM, AGM, ORKÖY ve MPGM) ve taşrada bu genel müdürlüklerin çok sayıda birimi vasıtasıyla yürütülmeye başlanmıştır. Ayrıca aynı yıl Ormancılık Araştırma Müdürlükleri (12 adet) Bakanlık taşra birimleri olarak yer almıştır (Daşdemir, 2015; Daşdemir, 2016a). 2003 yılında Orman Bakanlığı ve Çevre Bakanlığı birleştirilerek, 5856 sayılı yasa ile Çevre ve Orman Bakanlığı kurulmuştur. Bu gelişme ülke ve bilimsel gerçeklerle uyuşmamakla birlikte, bakanlıkların birleştirilmesi ile Türkiye ormancılık politikasında ormancılık örgütünün asimilasyon süreci başlatılmıștır (Akesen ve ark., 2007; Akesen, 2005).

03.06.2011 tarihli ve 636 say1lı Kanun Hükmünde Kararname ile kurulan, ama uygulanmayan 26 günlük Çevre, Orman ve Şehircilik Bakanlığı'ndan sonra, 29.6.2011 tarihinde 645 sayılı Kanun Hükmünde Kararname ile OSİB kurulmuştur. Daha önce genel müdürlük şeklinde örgütlenen AGM ve ORKÖY yeni örgütlenmede OGM daire başkanlıklarına dönüştürülmüştür. Bakanlığın yeni hizmet birimi olarak Çölleşme ve Erozyonla Mücadele Genel Müdürlüğü (ÇEM) ile Doğa Koruma ve Milli Parklar Genel Müdürlüğü (DKMP) kurulmuş ve böylece ormanc1lık faaliyetleri üç genel müdürlük (OGM, ÇEM ve DKMP) halinde yürütülmeye başlanmıştır. Ayrıca 29.6.2011'den önce Çevre ve Orman Bakanlığı'na (ÇOB) bağlı olan Ormancılık Araştırma Müdürlükleri de OGM'ye doğrudan bağlı Araştırma Enstitüleri haline getirilmiştir (Daşdemir, 2015; Daşdemir, 2016a; Daşdemir, 2016b). Bakanlık bünyesinde yer alan ve taşra teşkilatı olmayan ÇEM ve Su Yönetim Genel Müdürlüğünün (SYGM) taşradaki görevleri ise OGM ve DSİ tarafından yürütülmektedir. Halen bu şekilde bir örgütlenme ve yönetim anlayışı devam etmektedir.

OSİB bünyesinde 25 daire başkanlığı, yüzlerce orman ve su işleri uzmanı, uzman yardımcısı, 160 şube müdürlüğü, 349 programci-bilgisayar işletmeni-veri hazırlama ve kontrol işletmeni, 400'den fazla mühendis, vb. olmak üzere toplam 2.756 kadro oluşturulmuştur. Bakanlık taşra örgütünde ise çeşitli niteliklerde 6.044 kadro ihdas edilmiştir. OGM'nin merkez teşkilatı; Danışma ve Denetim Birimleri, Ana Hizmet Birimleri ve 
Yardımcı Hizmet Birimlerinden oluşmakta; Teftiş Kurulu Başkanlığı, Hukuk Müşavirliği ve İç Denetim Başkanlığı ile 18 daire başkanlığg ve bu daire başkanlıklarına bağlı toplam 118 şube müdürlüğü bulunmaktadır. Taşra teşkilatı 28 Orman Bölge Müdürlüğü ve doğrudan merkeze bağlı 12 Araştırma Enstitüsü Müdürlüğünden oluşmaktadır. Bölge Müdürlüklerine bağlı 245 Orman İşletme Müdürlüğü, 28 Orman Fidanlık Müdürlüğü, 5 müdürlük ve 86 Başmühendislik, orman işletme müdürlüklerine bağlı 1.416 Orman İşletme Şefliği, 22 Fidanlık Şefliği, 156 Ağaçlandırma ve Toprak Muhafaza Şefliği ve 222 diğer şeflik ile fidanlık müdürlüklerine bağlı 68 Fidanlık Şefliği mevcuttur (Anonim, 2017). Enstitü Müdürlüklerine ait 86 Başmühendislik ve 10 Araştırma Ormanı Mühendisliği bulunmaktadır (Anonim, 2012).

Görüldüğü gibi Türkiye ormancılığında örgütlenme ve örgüt yapısı tarihsel süreç içerisinde pek çok anlamsız ve başarısız reorganizasyona uğrayarak bugüne gelinmiştir. Ülkemizdeki ormancılıkla ilgili örgütlerin kuruluşu veya kapanışı ekonomik ve bilimsel ölçütlerden (ağaç serveti, üretim gücü, yatırım, kâr, fayda-masraf ilişkisi vb.) ziyade, tamamen merkezi ve politik kararlarla olmaktadır (Geray, 1982). Bu şekilde yapılan bir örgütlenmenin herhangi bir teknik, ekonomik ve sosyal analize dayandığ 1 söylenemez. Dolayısıyla, bu örgütlenme yapısının ülkemiz gereklerine ve çağdaş ormanc1lık anlayışına uygun olduğunu söylemek de güçtür.

\section{2. Çalışmanın amacı ve kapsamı}

Türkiye'de yaklaşık 180 yıllık geçmişe sahip olan ormanc1lı örgütünün konu ve alan itibariyle geniş bir yayılış göstermesi, merkezden yönetim anlay1Ş1 gibi etkenler örgüt işleyişinin ve yapısının gereksinmeleri tam olarak karşılayamamasına neden olmaktadır. Diğer yandan, kamu kurumlarının hantal yapıları, aşırı istihdam, yetki ve sorumluluğun iyi dağıtılamamış olması, engelleyici bürokratik zihniyet, siyasetin bürokrasi üzerindeki olumsuz etkileri gibi nedenlerle, kamu kesiminin öncü olmak yerine, gelişmelerin önünü tıkamakta olduğu bilinen bir gerçektir. Böylesi uzun bir geçmişe sahip olan ormancılık örgütünün sayılan sorunlara sahip olmaması düşünülemez. Belirtilen sorunları ortadan kaldırmak ve hızlı değişim dinamiğine uyum sağlayabilmek için örgütler kapsamlı ve radikal reformlara ihtiyaç duymaktadır. Kamu kurumlarının katı ve durağan organizasyon yapılarının değişiklik geçirmesi gerekmektedir (Barlı ve ark., 2000). Ormancılık örgütünün de bu anlamda değişime ihtiyacı vardır.

Türkiye'de ormancılık faaliyetlerinin bu şekilde örgütlenmesi çağdaş ormancılığa ve bütünleşik yönetime aykırı olup, kaynak savurganlığına neden olan ve bilimsel esaslara dayanmayan suni bir örgütlenmedir. Öteden beri uygulanan ormanc1lık örgütlenme modellerinde merkeziyetçilik, özerklik, esneklik, işbirliği, katılımcılık, eşgüdüm, bütünleşik yönetim vb. sorunlar vardır. Yani amaç birliği ve bütünleşik yönetimden uzak, eşgüdüm ve denetimin eksik olduğu, bilime, araştırmaya, rekabete ve motivasyona dayanmayan, yöneticilere yeterince özgürlük tanımayan, yerinden yönetime ve katılımcılığa önem vermeyen, yönetici atamalar1 objektif kriterlere bağlı olmayan, merkezi ve politik kararların yoğun olduğu bir ormancılık örgütlenmesi ve yönetim anlayışı vardır (Geray, 1989; Geray, 1993; Çağlar, 1993; Daşdemir, 1998; Daşdemir, 1999; Anonim, 2004; Gümüş, 2014b). Bu durumda yöneticilere özgürlük ve esneklik tanıyan, bilgiyi, uzmanlığı ve eğitimi öne çıkaran, amaç ve kısıtlarla uyumlu ve etkin çalışan, merkezi ve politik kararları dışlayan, özellikle taşrada ormancılık işletmesi denilen tek bir birim tarafından yönetilen ve böylece çağdaş ormancılık anlayışına uygun bir örgütlenme ve yönetim modelinin geliştirilmesi zorunludur (Daşdemir, 2015).

Dolayısıyla bu çalışma, Türkiye ormancılığında örgütlenme ve yönetim sorunlarının ve çözüm önerilerinin belirlenmesi, ülke koşullarına ve çağdaş ormancılık anlayışına uygun bir örgütlenme ve yönetim anlayışı modelinin geliştirilmesi, böylece ormancılığımızın bir sistem olarak aksayan yanlarının giderilmesine çözüm bulmak amacıyla ele alınmıştır. Bu çalışma OSİB'in ormancılık kesimindeki (OGM, DKMP ve ÇEM) merkez ve taşra örgütlenmesi kapsamında yürütülmüştür. Çalışmada örgütleme işlevi ile ilişkili konular arasındaki bağlantıların irdelenmesi, alternatif örgütlenme modellerinin geliştirilmesi ve bunların arasında önceliklendirme yapılması hedeflenmiştir. Bu kapsamda çalışmalar dört farklı ilgi grubunun (ormancılık örgütü çalışanları, uzmanlar, ilgili kurumlar ve STK temsilcileri) görüşlerinden yararlanılarak katılımcı yaklaşımla sürdürülmüştür.

\section{Materyal ve Yöntem}

\subsection{Materyal}

Bu çalışma, OSİB ormancılık kesimi (OGM, DKMP ve ÇEM) örnekleminde yürütülmüştür. Türkiye ölçeğinde dokuz bölgeyi temsil edecek şekilde ormanc1lık faaliyetlerinin yoğun olduğu iller (İstanbul, İzmir, Antalya, Adana, Bolu, Trabzon, Erzurum, Şanlıurfa ve Ankara) çalışma kapsamına alınmıştır.

Belirtilen illerde dört farklı ilgi grubunun (ormancılık örgütü çalışanları, konu uzmanları, kamu ku- 
rumları ve STK temsilcileri) bakışıyla Ormancılık Örgütünün mevcut durumunun, yönetim ve organizasyon sorunlarının ortaya konulması ve çağdaş ormancılık anlayışına uygun olarak alternatif örgütlenme ve yönetim anlayışı modellerinin geliştirilmesi için kişilerle görüşmeler yapılmış ve anket uygulanmıştır. Bu amaçla dört farklı ilgi grubu için anket formları geliştirilmiştir. Anket formlarında ana hatlarıyla; 1) Türkiye ormancılığının mevcut yönetim anlayışı ve ormancılık örgüt yapısı, 2) Türkiye ormancılığının yönetim ve organizasyon sorunları, 3) Alternatif örgütlenme ve yönetim modelleri üzerine değerlendirmeler ve öneriler konularında açık ve kapalı uçlu sorular yer almıştır. Görüşmelerde ise yarı yapılandırılmış görüşme tekniğinden faydalanılarak anket ile elde edilen bulgular hakkında daha detaylı ve katılımcıların bakış açısını daha açık şekilde belirleyebilecek sorulara yer verilmiştir. Dört farklı ilgi grubu ile yapılan anket ve görüşme çalışması ile literatür taramasından elde edilen her türlü nitel ve nicel veriler araştırmada materyal olarak kullanılmıştır.

\subsection{Veri toplama yöntemi}

OSİB ormancılık birimlerinin merkez ve taşra örgütlerinde yönetici ve teknik eleman olarak çal1şanların sayısı $(\mathrm{N}=4.704)$ araştırma evrenini oluşturmaktadır. Araştırma kapsamına alınan illerde anket yapılacak örgüt çalışanlarının sayısı, sınırlı toplumlarda örnek büyüklüğünü veren aşağıdaki formül yardımıyla (Orhunbilge, 2000; Daşdemir, 2016c) hesaplanmıştır;

$$
n \geq \frac{\mathrm{Z}^{2} * \mathrm{~N} * \mathrm{p} * \mathrm{q}}{\mathrm{N} * \mathrm{D}^{2}+\mathrm{Z}^{2} * \mathrm{p} * \mathrm{q}}
$$

Burada; n: Örnek büyüklüğünü, Z: Güven katsay1sını (\% 95 güven düzeyi için $Z=1,96), \mathrm{N}$ : Ana kütle büyüklüğünü $(\mathrm{N}=4.704)$ ve $\mathrm{D}$ : Kabul edilen örnek- leme hatasını $(0,05)$ göstermektedir. p ölçmek istenilen özelliğin ana kütlede bulunma olasılığg ve q ölçmek istenilen özelliğin ana kütlede bulunmama olasılığı, örnek büyüklüğünü en çoklamak için s1rasıyla $0,5-0,5$ alınmıştır.

Yukarıdaki verilere göre $n$ değeri 355 hesaplanmış ve en az bu kadar çalışanla görüşme yapılması gerektiği belirlenmiştir. Hesaplanan n/N katsayısı ile her bir bölgedeki çalışan sayısı çarpılarak, o bölgelerdeki görüşülecek asgari düzeydeki denek sayısı saptanmıştır. Yani her katmanda, hissesi oranında örnekleme yapılmıştır. Ancak çalışmada; 355 rakamı aşılarak 463 denekle görüşülmüştür (Tablo 2). Her bölgede görüşülen/anket yapılan kişiler ise rastgele örnekleme yöntemine göre belirlenmiştir. Böylece araştırmada katmanl1-basit rastgele örnekleme yöntemi uygulanmıştır.

Ayrıca araştırma kapsamına alınan illerde tam alan ölçüm yöntemine göre 32 ilgili kamu kurumu temsilcisi (Belediyeler, Orman Fakülteleri, Tarım İl Müdürlükler vb.), 37 STK temsilcisi (Orman Mühendisleri Odası, Türkiye Ormancılar Derneği, Çevre ve Kültür Değerlerini Koruma ve Tanıtma Vakfı, Ormancılık Kooperatifleri, Köy Muhtarları Derneği, Ormancılık Sendikası, vb.) ve 33 uzman (orman kaynakları yönetimi konusunda bilimsel çalışmaları bulunan veya ormancılık örgütünde uzun yıllar yöneticilik yapmış, örgütün yönetimi ve yeniden yapılandırılması konularında bilgisi olan kişiler) ile de anket çalışması yapılmıştır.

Mevcut örgüt yapısının değerlendirilmesi ve ortaya çıkan sorunlar kapsamında gerçekleşen görüşmelerden elde edilen veriler, anket yoluyla ulaşılan bulguları yorumlamada kullanılmıştır. Anketler, katılımcıların tamamına elden ulaştırılmış ve birçoğuna yüz yüze yöntemle uygulanmıştır. Görüşmeler de benzer şekilde yüz yüze yapılmış ve

Tablo 2. Ormancıl1k örgütünde çalışan ve görüşülen denek sayıs1

Table 2. The number of the employees (and the subjects) interviewed in the forestry organization

\begin{tabular}{|c|c|c|c|c|c|c|c|c|c|c|}
\hline \multirow{2}{*}{ Bölgeler/İller } & \multicolumn{2}{|c|}{ OGM } & \multicolumn{2}{|c|}{ DKMP } & \multicolumn{2}{|c|}{ ÇEM } & \multicolumn{2}{|c|}{ OSİB Merkez } & \multicolumn{2}{|c|}{ Toplam } \\
\hline & Çalışan & Denek & Çalışan & Denek & Çalışan & Denek & Çalışan & Denek & Çalışan & Denek \\
\hline Marmara (İstanbul) & 721 & 62 & 73 & 9 & & & & & 794 & 71 \\
\hline Ege (İzmir) & 693 & 59 & 57 & 5 & & & & & 750 & 64 \\
\hline Bat1 Akdeniz (Antalya) & 335 & 27 & 30 & 3 & & & & & 365 & 30 \\
\hline Doğu Akdeniz (Adana) & 459 & 49 & 30 & 15 & & & & & 489 & 64 \\
\hline Batı Karadeniz (Bolu) & 680 & 68 & 34 & 4 & & & & & 714 & 72 \\
\hline Doğu Karadeniz (Trabzon) & 364 & 30 & 20 & 4 & & & & & 384 & 34 \\
\hline İç Anadolu (Ankara) & 692 & 65 & 79 & 6 & 48 & 5 & 54 & 4 & 873 & 80 \\
\hline Doğu Anadolu (Erzurum) & 187 & 20 & 21 & 3 & & & & & 208 & 23 \\
\hline $\begin{array}{l}\text { Güney Doğu Anadolu (Şan- } \\
\text { liurfa) }\end{array}$ & 89 & 18 & 38 & 7 & & & & & 127 & 25 \\
\hline TOPLAM & 4.220 & 398 & 382 & 56 & 48 & 5 & 54 & 4 & 4.704 & 463 \\
\hline
\end{tabular}


Tablo 3. Araștırma değișkenlerinin tanımlanması Table 3. Identification of research variables

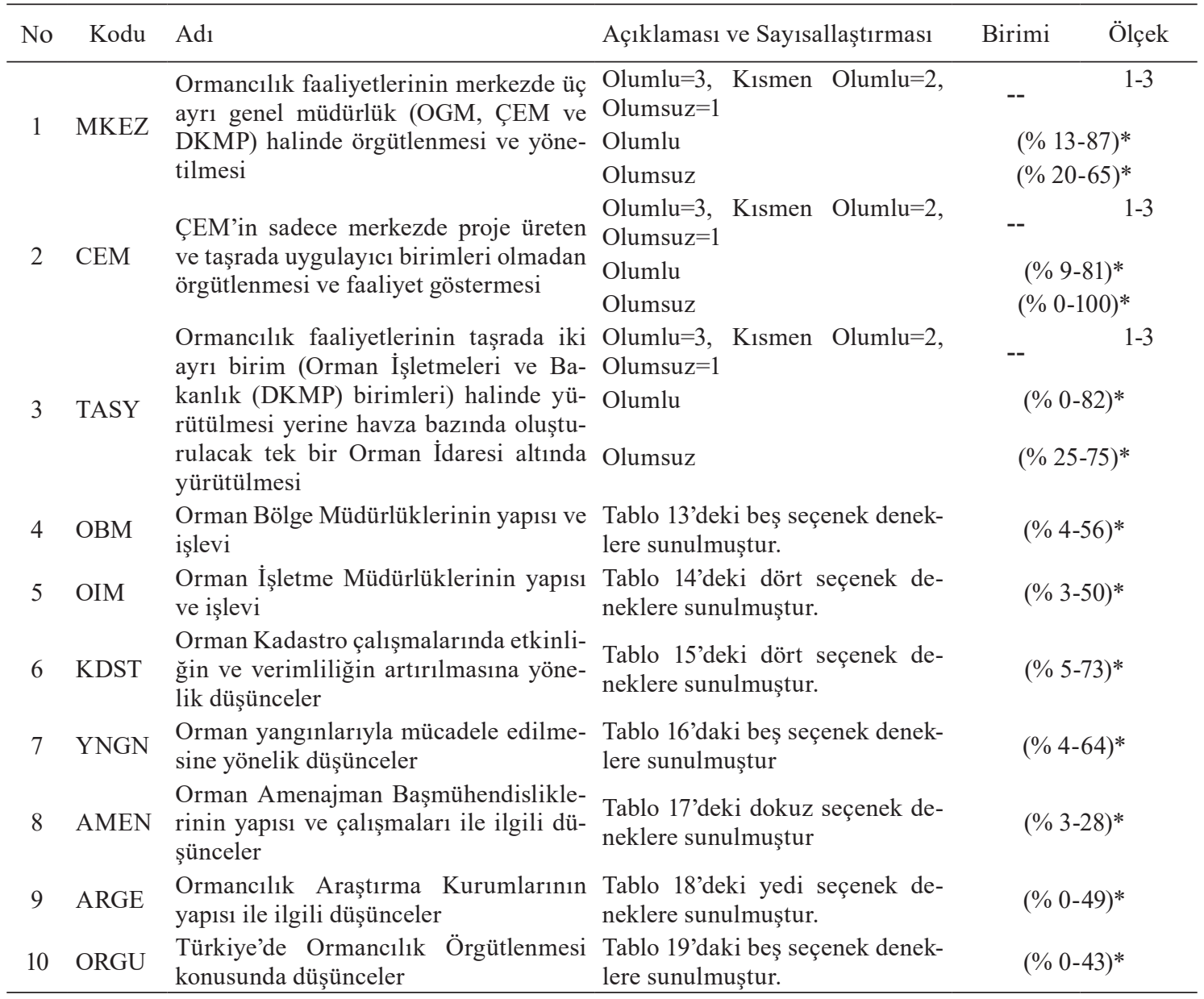

* Çalışanların ve uzmanların tercih yüzdeleri

Tablo 4. Ormancılık örgütü çalışanlarının idari görevde ve meslekteki süreleri ile eğitim durumları Table 4. Educational status, and administrative and vocational terms of employees in forestry organization

\begin{tabular}{|c|c|c|c|c|}
\hline \multirow{2}{*}{ Genel bilgiler } & \multirow{2}{*}{ Sinif } & \multirow{2}{*}{ Y1llar } & \multicolumn{2}{|c|}{ Çalışanlar } \\
\hline & & & Say1 & $\%$ \\
\hline \multirow{4}{*}{ İdari görevde geçen süre } & 1 & $0-5$ y11 & 301 & 65 \\
\hline & 2 & $6-10$ y1l & 100 & 22 \\
\hline & 3 & $\geq 11$ y1l & 62 & 13 \\
\hline & Toplam & & 463 & 100 \\
\hline \multirow{5}{*}{ Deneyim (meslekte geçen süre) } & 1. $\mathrm{Az}$ & $0-10$ y1l & 121 & 26 \\
\hline & 2. Orta & $11-20$ y1l & 117 & 25 \\
\hline & 3. Fazla & 21-30 y1l & 185 & 40 \\
\hline & 4. Çok fazla & $\geq 31$ y1l & 40 & 9 \\
\hline & Toplam & & 463 & 100 \\
\hline \multirow{4}{*}{ Eğitim Durumu } & Lisans & & 339 & 73 \\
\hline & Yüksek Lisans ve Doktora & & 111 & 24 \\
\hline & İki fakülte mezunu & & 13 & 3 \\
\hline & Toplam & & 463 & 100 \\
\hline
\end{tabular}


katılımcıların görüşleri not edilerek daha sonra değerlendirilmiş ve yorumlanmıştır.

Böylece, dört ilgi grubundan toplam 565 denekle yüz yüze görüşme usulüyle anket çalışmaları 2016 yılında gerçekleştirilmiştir.

\subsection{Verileri değerlendirme yöntemi}

Dört farklı ilgi grubu anketlerinden elde edilen ve çoğunluğu nitel olan sorular/veriler, çalışmanın amacına hizmet edecek şekilde (Tablo 3) birer değişken olarak tanımlanmış ve sayısallaştırmıştır.

Araştırmada elde edilen veriler betimsel istatistikler, Kruskal-Wallis H-Testi ve Duncan Testi ile değerlendirilmiş ve sonuçlar çizelgeler halinde gösterilmiştir. Verileri değerlendirmede Excel-2010 ve SPSS (22.0 version) programları kullanılmıştır.

\section{Bulgular}

\section{1. İlgi gruplarına ilişkin genel bulgular ve değerlendirmeler}

Araştırmada, Türkiye'nin 9 bölgesinde yer alan 4 ilgi grubundan toplam 565 kişiyle görüşme ve anket çalışması yapılmıştır. Bunlardan 463'ü ormanc1lık örgütünde yönetici ve teknik eleman olarak çalışmaktadır. Anket yapılan örgüt çalışanlarının $\%$ 59'u mühendis, \% 11'i orman işletme şefi, \% 2'si orman işletme müdür yardımcısı, \% 2'si orman işletme müdürü, \% 24'ü şube müdürü ve $\% 2$ 'si ise orman bölge müdürü, bölge müdür yardımcısı veya daire başkanıdır. Aynı şekilde görüşülen 33 uzmanın \% 52'si OSİB çalışanı, \% 42'si orman fakülteleri akademisyeni olarak görev yapmakta ve \% 6's1 ise emekli orman mühendisidir. Ankete katılan 32 ilgili kurum temsilcisinin \% 28'i belediyeler veya diğer bakanlıkların, \% 53'ü Orman Fakültelerinin, \% 19’u ormancılıkla ilişkili diğer kurumların (Devlet Su İşleri Genel Müdürlüğü, Karayolları Genel Müdürlüğü vb.) çalışanıdır. Bunlardan \% 34'ü teknik eleman, \% 13'ü yönetici ve \% 53'si akademisyen olarak görev yapmaktadır. Görüşülen 37 STK temsilcisinin \% 51'i Orman Mühendisleri
Odası veya Ormancılar Derneği'nin, \% 8'i sendikaların ve $\% 41$ 'i ormancılıkla ilgili vakıfların vb. üyesidir. Bunlardan \% 68'i üye, \% 32'si ise başkan veya başkan yardımcısıdır.

Türkiye genelinde ormanc1lık örgütünde yönetici ve teknik eleman olarak çalışan 463 deneğin idari görevlerde geçen süreleri, meslekte geçen süreleri ile eğitim durumları Tablo 4'te verilmiştir.

Buna göre, deneklerin \% 65'nin halen bulundukları idari görevlerinde 0-5 yıl süreyle çalıştıkları anlaşılmaktadır. 11 yıl veya daha fazla süreyle aynı idari görevde çalışanların oranı ise \% 13’tür. Yani idari görevde çalışan personelin \% 87'si görevlerini en fazla 10 yıl sürdürmüştür. Deneklerin \% 51'i meslekte 20 yıllık deneyime sahipken, \% 49’u 21 y1l ve daha fazla deneyime sahiptir. Deneklerin \% 73'ü Orman Fakültesi'nin Orman Mühendisliği Bölümü lisans mezunudur. Ancak \% 24'ü yüksek lisans veya doktora yapmış, \% 3'ü ise başka bir fakülteyi daha bitirmiştir. Bu durum nitelikli yönetici ve teknik eleman yetiştirilmesi adına önemli bir gelişmedir. Uzman olarak görüşülen deneklerin ise yaklaşık \% 70'i lisansüstü eğitim yapmış veya ikinci bir fakülte bitirmiştir.

\subsection{Merkezdeki örgütlenme ve örgüt yapısı}

"Türkiye'de ormanc1lık faaliyetlerinin merkezde OSİB'e bağll üç ayrl genel müdürlük (OGM, ÇEM ve DKMP) halinde örgütlenmesi ve yönetilmesi" konusunda çalışanların \% 18'i olumlu, \% 41'i olumsuz ve $\%$ 4l'i k1smen olumlu-k1smen olumsuz cevap verirken; uzmanların \% 15'i olumlu, \% 61'i olumsuz ve \% 24'ü k1smen olumlu-k1smen olumsuz değerlendirme yapmıştır. Buna göre çalışanların \% 82'si, uzmanların ise \% 85'i ormancılık faaliyetlerinin merkezde üç ayrı genel müdürlük (OGM, ÇEM ve DKMP) halinde örgütlenmesini ve yönetilmesini olumsuz veya kısmen olumsuz görmektedir Olumlu ve olumsuz görüş bildiren deneklerin bu konudaki gerekçeleri ise Tablo 5 ve 6'da verilmiştir.

Tablo 5. Ormancılığın üç ayrı genel müdürlük halinde örgütlenmesine ve yönetilmesine "olumlu” görüş bildirenlerin gerekçeleri

Table 5. Reasons for the "positive" opinions on the organization and management of the forestry in three separate general directorates

\begin{tabular}{lcc}
\hline Gerekçe & $\begin{array}{c}\text { Çalışanlar } \\
(\%)\end{array}$ & $\begin{array}{c}\text { Uzmanlar } \\
(\%)\end{array}$ \\
\hline a) Kaynakların kullanımında tasarruf sağlanmıştır. & 13 & 17 \\
b) Çok geniş çalışma alanına sahip olan Ormancılık Örgütünün merkezde makro planlar \\
dahilinde çalışması, her Genel Müdürlüğün kendi alanında uzmanlaşması ve iş bölü- \\
$\begin{array}{l}\text { mü yapması sayesinde iş yükü hafiflemiş, faaliyetler hızlanmış, iş verimliliği artmış } \\
\text { ve kurumsallaşma açısından avantaj sağlanmıştır. }\end{array}$
\end{tabular}


Tablo 6. Ormancılığın üç ayrı genel müdürlük halinde örgütlenmesine ve yönetilmesine "olumsuz" görüş bildirenlerin gerekçeleri

Table 6. Reasons for the "negative" opinions on the organization and management of the forestry in three separate general directorates

\begin{tabular}{|c|c|c|}
\hline Gerekçe & $\begin{array}{c}\text { Çalışanlar } \\
(\%)\end{array}$ & $\begin{array}{c}\text { Uzmanlar } \\
(\%)\end{array}$ \\
\hline $\begin{array}{l}\text { a) Devlet ormanlarının tek elden yönetilmemesine, otorite boşluğuna, Ormancılık } \\
\text { Örgütünün zayıf düşmesine yol açmış dolayısıyla; iş verimliliği azalmış, ormancılık } \\
\text { faaliyetleri (birimler) arasında koordinasyon zayıflamış ve bürokrasi artmıştır. }\end{array}$ & 35 & 20 \\
\hline $\begin{array}{l}\text { b) Yapılacak iş ve işlemlerde gereksiz iş yüküne, zaman kaybına, maliyetlerin artmasına } \\
\text { ve denetimin azalmasına neden olmuştur. }\end{array}$ & 17 & 15 \\
\hline $\begin{array}{l}\text { c) Kurumlar arası çok başlı yönetime, yetki-sorumluluk çatışmasına ve karar verme } \\
\text { sürecinde kargaşaya neden olmuştur. Fiziksel ve beşeri imkanlar etkin olarak kulla- } \\
\text { nılamamakta, olumsuz yönde siyasi baskıya ve rekabete açık kalınmaktadır. }\end{array}$ & 48 & 65 \\
\hline
\end{tabular}

“ÇEM'in sadece merkezde proje üreten ve taşrada uygulayıcı birimleri olmadan örgütlenmesini ve faaliyet göstermesini" çalışanların \% 7'si olumlu, $\%$ 76's1 olumsuz ve \% 17'si ise kısmen olumlukısmen olumsuz görüş bildirmiştir. Uzmanların ise $\%$ 6's1 olumlu, \% 76's1 olumsuz ve \% 18'i ise k1smen olumlu-kısmen olumsuz cevap vermiştir. Yani çalışanların \% 93'ü ve uzmanların \% 94'lük kesimi ÇEM'in taşrada uygulama birimleri olmadan örgütlenmesini ve faaliyet göstermesini olumsuz veya k1smen olumsuz değerlendirmektedir. Olumlu ve olumsuz görüş bildiren deneklerin bu konudaki gerekçeleri ise Tablo 7 ve 8 'de verilmiştir.

Tablo 7. ÇEM'in merkezdeki örgütlenmesi ile ilgili “olumlu” görüş bildirenlerin gerekçeleri Table 7. Reasons for the "positive" opinions on the organization of GDCDE in the center

\begin{tabular}{lcc}
\hline Gerekçe & $\begin{array}{c}\text { Çalışanlar } \\
(\%)\end{array}$ & $\begin{array}{c}\text { Uzmanlar } \\
(\%)\end{array}$ \\
\hline a) Kaynakların kullanımında tasarruf sağlanmıştır. & 41 & 0 \\
b) Çok geniş çalışma alanına sahip olan Ormancılık Örgütünün merkezde makro plan- \\
lar dahilinde çalışması, her bir genel müdürlüğün kendi alanında ihtisaslaşması ve iş \\
$\quad \begin{array}{l}\text { bölümü yapması sayesinde iş yükü hafiflemiş, faaliyetler hızlanmış, iş verimliliği } \\
\text { artmış sonuçta, kurumsallaşma açısından avantaj sağlanmıştır. }\end{array}$ & 59 & 100 \\
\hline
\end{tabular}

Tablo 8. ÇEM'in merkezdeki örgütlenmesi ile ilgili “olumsuz” görüş bildirenlerin gerekçeleri Table 8. Reasons for the "negative" opinions on the organization of GDCDE in the center

\begin{tabular}{|c|c|c|}
\hline Gerekçe & $\begin{array}{l}\text { Çalışanlar } \\
(\%)\end{array}$ & $\begin{array}{l}\text { Uzmanlar } \\
(\%)\end{array}$ \\
\hline $\begin{array}{l}\text { a) Taşrada örgütlenmesi olmayan Genel Müdürlüğün merkezde yapmış olduğu projelerin } \\
\text { taşrada başka birimlerce uygulanması başarısızlığa neden olmakta, takibini ve } \\
\text { kontrolünü zorlaştırmaktadır. Şu an yaptığı AR-GE işidir. }\end{array}$ & 82 & 81 \\
\hline $\begin{array}{l}\text { b) Yapılacak iş ve işlemlerde gereksiz iş yüküne, zaman kaybına, maliyetlerin artmasına } \\
\text { ve denetimin azalmasına neden olmuştur. }\end{array}$ & 11 & 10 \\
\hline $\begin{array}{l}\text { c) Kurumlar arası çok başlı yönetime, yetki-sorumluluk çatışmasına ve karar verme } \\
\text { sürecinde kargaşaya neden olmuştur. }\end{array}$ & 7 & 9 \\
\hline
\end{tabular}

Merkezde ormancılık faaliyetlerinin üç ayrı birim halinde yürütülmesi konusunda örgüt çalıșanlarının düşünceleri görev ve deneyime göre farklılık göstermemektedir. Ancak bölgelere göre \% 99 güven düzeyinde, çalışılan birime göre ise \% 95 güven düzeyinde farklılık oluşturmaktadır. Farklı grupları bulmak amacıyla yapılan Duncan Testi sonuçlarına göre; genel olarak İzmir Bölgesi’nde çalışanlar ormancılık faaliyetlerinin üç ayrı birim halinde yü- rütülmesine olumsuz bakarken, Ankara, Trabzon, Erzurum, Şanlıurfa, Adana ve Antalya bölgelerinde çalışanlar kısmen olumlu-kısmen olumsuz, Bolu Bölgesi'nde çalışanlar ise olumlu bakmaktadırlar. Aynı şekilde çalışılan birime göre de, ÇEM ve OGM çalışanları ormancılık faaliyetlerinin üç ayrı birim halinde yürütülmesine olumsuz bakarken, DKMP çalışanları daha olumlu bakmaktadır. Diğer yandan çalışanların, ÇEM'in taşrada uygulama birimleri 
olmadan sadece merkezde örgütlenmesi ve faaliyet görev ve deneyime göre farkl1l1k göstermemektedir göstermesi konusunda düşünceleri ise bölge, birim, (Tablo 9).

Tablo 9. Ormancılığın merkezdeki örgütlenmesi ve yönetimine ilişkin görüşlerin bölge, birim, görev ve deneyime göre farkl1lı̆̆

Table 9. Differences in views on the organization and management of the forestry in the center, according to the region, unit, task and experience

\begin{tabular}{|c|c|c|c|c|c|c|c|}
\hline \multirow{3}{*}{ Özellikler } & \multicolumn{3}{|c|}{$\begin{array}{c}\text { Kruskal-Wallis H-Testi } \\
\text { sonuçları }\end{array}$} & \multicolumn{4}{|c|}{ Duncan testi ile farklılık denetimi } \\
\hline & \multirow{2}{*}{ Kriter } & \multirow{2}{*}{$\begin{array}{c}\text { Khi-kare } \\
\text { değeri }\end{array}$} & \multirow{2}{*}{ SD } & \multicolumn{4}{|c|}{ Farklı gruplar } \\
\hline & & & & No & Grup elemanları & $\overline{\mathrm{X}}$ & $\mathrm{N}$ \\
\hline \multirow{6}{*}{$\begin{array}{l}\text { 1. Merkezde ormancılık faaliyetleri- } \\
\text { nin üç ayrı birim halinde yürütülme- } \\
\text { si ile ilgili değerlendirme }\end{array}$} & \multicolumn{5}{|c|}{ Görev ve deneyim açısından anlamlı bir fark yoktur } & -- & -- \\
\hline & \multirow{3}{*}{ Bölge } & \multirow{3}{*}{$21,30^{* *}$} & \multirow{3}{*}{8} & 1 & İzmir & 1,55 & 64 \\
\hline & & & & 2 & $\begin{array}{l}\text { Ankara, Trabzon, Erzu- } \\
\text { rum, Şanliurfa, Adana, } \\
\text { Antalya }\end{array}$ & 1,77 & 327 \\
\hline & & & & 3 & Bolu & 2,07 & 72 \\
\hline & \multirow{2}{*}{ Birim } & \multirow{2}{*}{$8,74^{*}$} & \multirow{2}{*}{2} & 1 & ÇEM, OGM & 1,67 & 410 \\
\hline & & & & 2 & DKMP & 2,06 & 53 \\
\hline
\end{tabular}

2. ÇEM'in merkez örgütlenmesi ve Bölge, birim, görev ve deneyim açısından anlamlı bir fark _-_ _faaliyet göstermesi ile ilgili düşünce yoktur

*: 0,05 güven düzeyinde anlamlı; **: 0,01güven düzeyinde anlamlı

\subsection{Taşradaki örgütlenme ve örgüt yapısı}

"Taşrada şu an ormancılık faaliyetlerinin (odun üretimi, odun dişı bitkisel ürünler üretimi, OR$K O ̈ Y$, doğa koruma ve milli parklar, av-yaban hayatı, ăgaçlandırma, mera, erozyon kontrolü, halkla ilişkiler vb.) iki ayrı birim (Orman İşletmeleri ve Bakanlık (DKMP) birimleri) halinde yürütülmesi yerine, havza bazında oluşturulacak tek bir Orman İdaresi/işletmesi çatısı altında yürütülmesi” konu- sunda çalışanların \% 54'ü olumlu, \% 20'si olumsuz ve \% 26'sı kısmen olumlu-kısmen olumsuz görüş bildirmiștir. Uzmanların ise \% 61'i olumlu, \% 21 'si olumsuz ve \% 18'i ise k1smen olumlu-k1smen olumsuz değerlendirme yapmıştır. Yani bu konuda çalışanların \% 80’i (54+26), uzmanların ise \% 79'u “olumlu veya k1smen olumlu” değerlendirme yapmıştır. Olumlu ve olumsuz görüş bildiren deneklerin bu konudaki gerekçeleri ise Tablo 10 ve 11'de verilmiştir.

Tablo 10. Taşrada tek bir orman idaresine "olumlu" görüş bildirenlerin gerekçeleri Table 10. Reasons for the "positive" opinions on a single forest administration in the province

\begin{tabular}{lcc}
\hline Gerekçe & $\begin{array}{c}\text { Çalışanlar } \\
(\%)\end{array}$ & $\begin{array}{c}\text { Uzmanlar } \\
(\%)\end{array}$ \\
\hline $\begin{array}{l}\text { a) Orman kaynaklarının bir bütünlük anlayışı içerisinde rasyonel yönetilmesi sağlanacak } \\
\text { ve çok başlılık ortadan kalkacaktır. Havza bazında her yörenin kendi ihtiyaçlarına }\end{array}$ & 82 & 82 \\
& öncelik verilir. & \\
$\begin{array}{l}\text { b) Kaynaklar daha organize ve ekonomik ş̧ekilde kullanılır, yapılacak iş ve işlemlerde } \\
\text { hızlı karar alma, uygulama ve verimlilik sağlanır. }\end{array}$ & 13 & 18 \\
$\begin{array}{l}\text { c) Planlama, yürütme, denetim ve eşgüdüm sorunlarının azalması, böylece motivasyo- } \\
\text { nun, üretimin, verimliliğin ve başarının artması sağlanır. }\end{array}$ & 5 & 0 \\
\hline
\end{tabular}

Ormancılık faaliyetlerinin taşrada iki ayrı birim halinde yürütülmesi yerine, tek çatı altında birleştirilerek yürütülmesi konusunda örgüt çalışanlar1nın düşünceleri göreve ve deneyime göre farklılık göstermemektedir. Ancak bölgelere ve çalış1lan birime göre ise \% 95 güven düzeyinde farklıdır.
Duncan Testi sonuçlarına göre, \% 95 güven düzeyinde Trabzon, Erzurum, Antalya ve İzmir bölgelerinde çalışanlar ormancılık faaliyetlerinin "taşrada tek bir Orman İdaresi/işletmesi çatısı altında yürütülmesi" düşüncesine İstanbul, Ankara, Bolu, Şanlıurfa ve Adana bölgeleri çalışanlarına 
Tablo 11. Taşrada tek bir orman idaresine "olumsuz" görüș bildirenlerin gerekçeleri

Table 11. Reasons for the "negative" opinions on a single forest administration in the province

\begin{tabular}{lcc}
\hline Gerekçe & $\begin{array}{c}\text { Çalışanlar } \\
(\%)\end{array}$ & $\begin{array}{c}\text { Uzmanlar } \\
(\%)\end{array}$ \\
\hline a) İş yükünün artmasına ve birimler arasında koordinasyonun zayıflamasına neden olur. & 49 & 25 \\
b) Çalışma alanları aynı olsa da, farklı uzmanlık alanları farklı örgütlenmeyi gerektirir. \\
$\quad \begin{array}{l}\text { Çalı̧̧ma sistemleri ve mevzuatları farklıdır. Uzmanlıkların ikinci plana atılması } \\
\text { verimsizliğin artmasına neden olacaktır. }\end{array}$ \\
\hline
\end{tabular}

göre daha fazla olumlu baktıkları anlaşılmaktadır. Çalışılan birime göre \% 95 güven düzeyinde; ÇEM çalışanları bu düşünceye kısmen olumlu-kısmen olumsuz bakarken, OGM ve DKMP çalışanları genel olarak olumlu bakmaktadır (Tablo 12).

Ankete katılan deneklerin "Orman Bölge Müdürlüklerinin (OBM) yapısı ve işlevleri” ile ilgili düşünceleri ve değerlendirmeleri ise Tablo 13'te verilmiştir. Gerek çalışanların (\% 56), gerekse uzmanların (\% 46) çoğunluğu “OBM'nin siyasi ve bürokratik bir makam olmaktan çıkartılarak bölgesindeki Orman İşletmeleri arasında eşgüdümü sağlayan ve onları yönlendiren birimler haline getirilmesini” istemektedir. Bu konuda yapılan Krus-

Tablo 12. Taşrada tek bir orman idaresine ilişkin görüşlerin bölge, birim, görev ve deneyime göre farklılı̆̆ 1 Table 12. Differences in views of a single forest administration in the province by region, unit, task and experience

\begin{tabular}{|c|c|c|c|c|c|c|c|c|}
\hline \multirow{2}{*}{ Özellikler } & \multicolumn{3}{|c|}{$\begin{array}{l}\text { Kruskal-Wallis H-testi } \\
\text { sonuçları }\end{array}$} & \multicolumn{5}{|c|}{ Duncan testi ile farkl1lık denetimi } \\
\hline & Kriter & $\begin{array}{l}\text { Khi-kare } \\
\text { değeri }\end{array}$ & SD & No & $\begin{array}{r}\text { Farklı gru } \\
\text { Grup elemanlar }\end{array}$ & uplar & $\overline{\mathrm{X}}$ & $\mathrm{N}$ \\
\hline \multirow{5}{*}{$\begin{array}{l}\text { 1. Taşrada ormancılık faaliyetle- } \\
\text { rinin iki ayrı birim halinde yü- } \\
\text { rütülmesi yerine tek çatı altında } \\
\text { birleştirilmesi ile ilgili düşünce- } \\
\text { ler }\end{array}$} & \multicolumn{6}{|c|}{ Görev ve deneyim kriterleri açısından bir fark yoktur } & -- & -- \\
\hline & \multirow{2}{*}{ Bölge } & \multirow{2}{*}{$15,80^{*}$} & \multirow{2}{*}{8} & 1 & $\begin{array}{l}\text { İstanbul, Ankara, } \\
\text { Şanlıurfa, Adana }\end{array}$ & & 2,27 & 312 \\
\hline & & & & 2 & $\begin{array}{l}\text { Trabzon, Erzurum, } \\
\text { İzmir }\end{array}$ & Antalya, & 2,47 & 151 \\
\hline & \multirow{2}{*}{ Birim } & \multirow{2}{*}{$6,10^{*}$} & \multirow{2}{*}{2} & 1 & ÇEM & & 2,00 & 5 \\
\hline & & & & 2 & OGM, DKMP & & 2,24 & 458 \\
\hline
\end{tabular}

2. Orman Bölge Müdürlükleri-

nin yapısı ve işlevleri ile ilgili Bölge, birim, görev ve deneyim açısından anlamlı bir fark yoktur -- _ -düşünceler

3. Orman İşletme Müdürlükleri-

nin yapısı ve işlevi ilgili düşün- Bölge, birim, görev ve deneyim açısından anlamlı bir fark yoktur -- _ -celer

4. Orman kadastro çalışmaların-

da etkinliğin ve verimliliğin ar- Bölge, birim, görev ve deneyim açısından anlamlı bir fark yoktur -- - -tırılması ile ilgili düşünceler

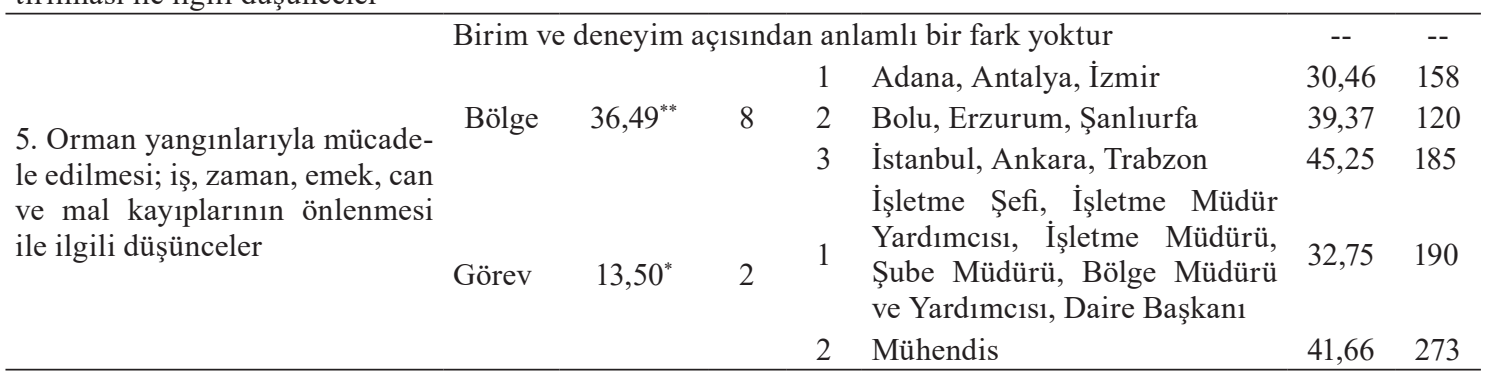

6. Orman Amenajman Başmü-

hendisliklerinin yapısı ve çalış- Bölge, birim, görev ve deneyim açısından anlamlı bir fark yoktur -- -maları ile ilgili düşünce

7. Ormancılık Araştırma Ku-

rumlarının yapısı ile ilgili dü- Bölge, birim, görev ve deneyim açısından anlamlı bir fark yoktur -- -şünce

*: 0,05 güven düzeyinde anlaml1; **: 0,01 güven düzeyinde anlamlı 
kal-Wallis H-Testi sonuçlarına göre (Tablo 12), OBM yapısı ve işlevleri ile ilgili düşüncelerin bölgelere, çalışılan birime, göreve ve deneyime göre

istatistiksel olarak anlamlı farklılık göstermediği saptanmıştır.

Tablo 13. Orman bölge müdürlüklerinin yapısı ve işlevi ile ilgili düşünceler

Table 13. The opinions on the structure and the function of the regional directorates of forestry

\begin{tabular}{lcc}
\hline Düşünce/ değerlendirme & $\begin{array}{c}\text { Çalışanlar } \\
(\%)\end{array}$ & $\begin{array}{c}\text { Uzmanlar } \\
(\%)\end{array}$ \\
\hline a) Tamamen kaldırılmalıdır. & 11 & 9 \\
b) Mevcut yapıları ve işlevleri muhafaza edilmelidir. & 11 & 3 \\
c) Sayıları azaltılıp Araştırma Enstitüleri ile birleştirilerek havza bazında örgütlen- \\
miş, Orman İşletmelerine danışmanlık yapan, özerk yapıda OAGD birimlerine \\
dönüştürülmelidir. \\
$\begin{array}{l}\text { d) Siyasi ve bürokratik makam olmaktan çıkartılarak bölgesindeki Orman İşletmeleri } \\
\text { arasında eşgüdümü sağlayan ve onları yönlendiren birimler haline getirilmelidir. }\end{array}$ \\
e) Diğer
\end{tabular}

Deneklerin "Orman İşletme Müdürlüklerinin (OIM) yapısı ve işlevleri” ile ilgili düşünceleri ve değerlendirmeleri Tablo 14'te verilmiştir. Buna göre gerek çalışanların (\% 50), gerekse uzmanların (\% 49) çoğunluğu "orman işletmelerinin havza bazında örgütlenmiş, merkeziyetçilikten ve politik baskılardan uzak, kararlarını katılımcı bir yaklaşımla alan, organik bakımdan ormancılık araştırma-geliştirme ve denetleme (OAGD) birimine bağll çalışan ve şube müdürlükleri veya başmühendisliklerden oluşan bir yapıya kavuşturulmasını" is- temektedir. Bu konuda deneklerin düşüncelerinin bölgelere, çalışılan birime, göreve ve deneyime göre istatistiksel olarak anlamlı farklılık göstermediği saptanmıştır (Tablo 12).

Deneklerin "orman kadastro çalışmalarında etkinlik ve verimliliğin artırılması" ilgili düşünceleri ve değerlendirmeleri Tablo 15'te verilmiştir. Buna göre gerek çalışanların (\% 68), gerekse uzmanların (\% 73) büyük çoğunluğu "genel kadastro komisyonlarına yeterli sayıda uzman orman mühendisi

Tablo 14. Orman işletme müdürlüklerinin yapısı ve işlevi ile ilgili düşünceler

Table 14. The opinions on the structure and the function of the forest district directorates

\begin{tabular}{|c|c|c|}
\hline Düşünce/ değerlendirme & $\begin{array}{c}\text { Çalışanlar } \\
(\%)\end{array}$ & $\begin{array}{c}\text { Uzmanlar } \\
(\%)\end{array}$ \\
\hline a) Mevcut sayıları, yapıları ve işleyişleri muhafaza edilmelidir. & 22 & 3 \\
\hline $\begin{array}{l}\text { b) Mevcut sayıları azaltılarak OGM emir-kumanda hiyerarşisi içerisinde çalışan, ancak } \\
\text { şube müdürlükleri veya başmühendisliklerden oluşan bir yapıya kavuşturulmalıdır. }\end{array}$ & 20 & 18 \\
\hline $\begin{array}{l}\text { c) Havza bazında örgütlenmiş, merkeziyetçilikten ve politik baskılardan uzak, kararları- } \\
\text { nı katılımcı yaklaşımla alan, organik bakımdan OAGD birimine bağlı olarak çalışan, } \\
\text { şube müdürlükleri veya başmühendisliklerden oluşan bir yapıya kavuşturulmalıdır. }\end{array}$ & 50 & 49 \\
\hline d) Diğer & 8 & 30 \\
\hline
\end{tabular}

Tablo 15. Orman kadastro çalışmalarının etkinliği ve verimliliği ile ilgili düşünceler Table 15. The opinions on the effectiveness and the productivity of forest cadaster works

\begin{tabular}{lcc}
\hline Düşünce/ değerlendirme & $\begin{array}{c}\text { Çalı̧anlar } \\
(\%)\end{array}$ & $\begin{array}{c}\text { Uzmanlar } \\
(\%)\end{array}$ \\
\hline $\begin{array}{l}\text { a) Eskiden olduğu gibi sadece orman kadastro komisyonlarınca yürütülmelidir } \\
\text { b) Orman kadastro çalışmaları mevcut haliyle genel kadastro komisyonlarınca, 2-B } \\
\text { çalışmaları ise orman kadastro komisyonlarınca yürütülmelidir }\end{array}$ & 11 & 9 \\
$\begin{array}{l}\text { c) Tapu ve kadastro komisyonlarına yeterli sayıda uzman orman mühendisi verilerek, } \\
\text { orman kadastro komisyonları kaldırılmalı ve orman kadastrosu çalışmaları tapu ve } \\
\text { kadastro komisyonlarınca (tek bir kurum tarafından) yürütülmelidir }\end{array}$ & 68 & 73 \\
d) Diğer & 5 & 6 \\
\hline
\end{tabular}


verilerek, orman kadastro komisyonlart kaldırılmalı ve orman kadastrosu çalışmaları genel kadastro komisyonlarınca (tek bir kurum tarafindan) yürütülmelidir" şeklinde bir değerlendirmede bulunmuştur. $\mathrm{Bu}$ konudaki değerlendirmelerin ise bölgelere, çalışılan birime, göreve ve deneyime göre istatistiksel olarak anlamlı fark göstermediği anlaşılmıştır (Tablo 12).

Deneklerin "orman yangınlarlyla mücadele edilmesi; iş, zaman, emek, can ve mal kayıplarının önlenmesi” ile ilgili düşünce ve değerlendirmeleri Tablo 16'da verilmiştir. Buna göre, deneklerin çoğunluğu (çalışanlar \% 58 ve uzmanlar \%6 4) orman yangınlarıyla mücadele çalışmalarını genel olarak başarılı bulmaktadır. Ağırlıklı olarak orman yangınlarıyla ilgili birimleri güçlendirme ve sistemin muhafaza edilmesi yönündeki düşüncenin ağ1rlık kazandığı görülmektedir. Ancak bu konudaki düşünceler bölgelere göre \%99 güven düzeyinde ve göreve göre \% 95 güven düzeyinde farklılık göstermektedir. Buna göre, Türkiye'de bütün bölgelerdeki çalışanlar genel olarak orman yangınlarıyla mücadelede mevcut sistemin kalmasından yana görüş bildirmesine rağmen, ağırlıklı olarak en fazla İstanbul, Ankara ve Trabzon bölgelerinde çalışanlar, ikinci olarak Bolu, Erzurum, Şanlıurfa ve üçüncü olarak da Adana, Antalya ve İzmir bölgelerinde çalışanlar mevcut sistemin geliştirilerek korunması yönünde görüş bildirmişlerdir. Aynı şekilde mühendis olarak görev yapanlar, işletme şefi, işletme müdür yardımcısı, işletme müdürü, şube müdürü, bölge müdürü ve yardımcısı, daire başkanı olarak görev yapanlara göre genel olarak daha fazla mevcut yapının geliştirilerek muhafaza edilmesi gerektiğini düşünmektedir. Diğer yandan orman yangınlarıyla mücadele edilmesin konusundaki düşüncelerin çalışılan birime ve deneyime göre farklı olmadı̆̆ı anlaşılmıştır (Tablo 12).

Tablo 16. Orman yangınlarıyla mücadele edilmesi ile ilgili düşünceler Table 16. The opinions on combating forest fires

\begin{tabular}{lcc}
\hline Düşünce/ değerlendirme & $\begin{array}{c}\text { Çalışanlar } \\
(\%)\end{array}$ & $\begin{array}{c}\text { Uzmanlar } \\
(\%)\end{array}$ \\
\hline a) Mevcut orman yangınlarıyla mücadele birimleri güçlendirilerek muhafaza edilmelidir. & 58 & 64 \\
b) Yangınla ilgili birimler kaldırılıp orman yangınlarını söndürme çalışmaları itfaiyelere & 10 & 18 \\
bırakılmalıdır. & 12 & 0 \\
c) Ayrı bir Genel Müdürlük tarafından yürütülmelidir. & 16 & 12 \\
d) Valiliklerin kontrolünde oluşturulacak bir örgüt tarafından yürütülmelidir. & 4 & 6 \\
e) Diğer & & 12 \\
\hline
\end{tabular}

Deneklerin "Orman Amenajman Başmühendisliklerinin yapısı ve çalışmaları" ile ilgili düşünceleri ve değerlendirmeleri Tablo 17'de verilmiştir. Tablo 17'ye göre, hiçbir seçenek belirgin bir farkla öne çıkmamaktadır. Ancak "coğrafi bölgelerde Orman İdaresi ve Planlama Dairesi Başkanlığına (OIP-
DB) bağlı taşra teşkilatı şeklinde yapılanmalı” seçeneğinin (çalışanlar \% 21 ve uzmanlar \% 28) diğer seçeneklere göre daha fazla tercih edildiği anlaşılmaktadır. Deneklerin bu konudaki düşünceleri bölgelere, birimlere, göreve ve deneyime göre farkl11ık göstermemektedir (Tablo 12).

Tablo 17. Orman amenajman başmühendisliklerinin yapısı ile ilgili düşünceler

Table 17. The opinions on the structure of forest management chief engineering

\begin{tabular}{lcc}
\hline Düşünce/ değerlendirme & $\begin{array}{c}\text { Çalışanlar } \\
(\%)\end{array}$ & $\begin{array}{c}\text { Uzmanlar } \\
(\%)\end{array}$ \\
\hline a) Mevcut durum korunmalı & 14 & 12 \\
b) OİPDB, bağlı Başmühendislikler şeklinde merkezde yapılanmalı & 14 & 9 \\
c) Coğrafi bölgelerde OİPDB, bağlı taşra teşkilatı şeklinde yapılanmalı & 21 & 28 \\
d) Coğrafi bölgelerde bazı bölge müdürlüklerine bağlı başmühendislikler şeklinde olmalı & 9 & 15 \\
e) Her Bölge Müdürlüğüne bağlı Başmühendislikler şeklinde yapılanmalı & 19 & 6 \\
f) Orman amenajman çalışmaları serbest mühendislik ve müşavirlik yoluyla yaptırılmalı & 13 & 21 \\
g) Orman İşletme Müdürlükleri veya şefliklerdeki teknik elemanlarca yapılmalı & 4 & 0 \\
h) Ayrı bir Genel Müdürlüğe bağlı Başmühendislikler şeklinde yapılanmalı & 3 & 0 \\
i) Diğer & 3 & 9 \\
\hline
\end{tabular}


Deneklerin “ormancılık araştırma kurumlarının (Ormancılık Araştırma Enstitüleri) organizasyon yapısı" ile ilgili düşünceleri; ağırlıklı olarak "ormancılık araştırma kurumlarının merkezde OGM'ye bağlı Araştırma-Geliştirme Dairesi Başkanlığı, taşrada ise bölgesel bazda örgütlenmesi şeklinde ortaya çıkmıştır (çalışanlar \% 45 ve uzmanlar \% 49) (Tablo 18). Diğer taraftan deneklerin bu konudaki görüşleri bölgelere, birimlere, göreve ve deneyime göre farklılık oluşturmamaktadır (Tablo 12).

Tablo 18. Ormancılık araştırma kurumlarının organizasyon yapısı ile ilgili düşünceler Table 18. The opinions on the organization structure of forestry research institutions

\begin{tabular}{|c|c|c|}
\hline Düşünce/ değerlendirme & $\begin{array}{c}\text { Çalışanlar } \\
(\%)\end{array}$ & $\begin{array}{c}\text { Uzmanlar } \\
(\%)\end{array}$ \\
\hline a) Bugünkü örgüt yapısı içerisindeki yeri gayet uygundur. & 8 & 0 \\
\hline b) Tamamen kaldırılmalı bilgi ihtiyacı üniversitelerden karşılanmalı & 15 & 6 \\
\hline $\begin{array}{l}\text { c) Bakanlığa bağlı Genel Müdürlük şeklinde örgütlenmeli ve taşrada mevcut yapı } \\
\text { korunmalıdır. }\end{array}$ & 16 & 27 \\
\hline $\begin{array}{l}\text { d) Merkezde OGM'ye bağlı Dairesi Başkanlığı, taşrada bölgesel bazda örgütlenmiş, } \\
\text { araştırma yapan, uygulamaya yardımcı olan, yol gösteren ve denetleyen OAGD birim- } \\
\text { leri şeklinde örgütlenmelidir. }\end{array}$ & 45 & 49 \\
\hline $\begin{array}{l}\text { e) Taşrada Orman Bölge Müdürlüklerine bağlı veya Bölge Müdürlüğü ile bütünleşik } \\
\text { birimler şeklinde örgütlenmelidir. }\end{array}$ & 11 & 0 \\
\hline f) Bakanlığın her genel müdürlüğü için ayrı ayrı araştırma birimleri oluşturulmalıdır. & 3 & 0 \\
\hline g) Diğer & 2 & 18 \\
\hline
\end{tabular}

\subsection{Alternatif örgütlenme ve yönetim modelleri}

Deneklere (çalışanlar, uzmanlar, ilgili kurum ve STK temsilcileri) "Türkiye'deki ormancılık örgütlenmesi” konusunda dört ayrı model sunulmuş ve düşünceleri Tablo 19'da derlenmiştir. Buna göre denekler alternatif örgütlenme modellerinden birinci strada Model-3’ü (\% 38), ikinci sirada Model-2'yi (\% 25), üçüncü sırada Model-4'ü (\% 23) ve son strada Model-1'i (\% 4) tercih etmiştir.
Buradan anlaşılacağı üzere, denekler Ormancılık Örgütünün merkezde tek genel müdürlük (OGM) veya farklı genel müdürlükler şeklinde yapılandırılabileceği, ancak taşrada güçlü bir Orman İdaresi altında yapılandırılması gerektiği düşüncesindedir. Diğer yandan deneklerin bu konudaki düşüncelerinin bölgelere, birimlere, göreve ve deneyime göre farklılık olmadığı, yapılan Kruskal-Wallis H-Testi sonuçlarından anlaşılmıştır (ortalama $\chi^{2}=6,56$; $\mathrm{P}=0,236>0,05)$.

Tablo 19. Türkiye'de ormanc1lık örgütlenmesi konusundaki düşünceler Table 19. The opinions on the forestry organization in Turkey

\begin{tabular}{|c|c|c|c|c|c|c|}
\hline $\begin{array}{l}\text { Model } \\
\text { No }\end{array}$ & Model açıklaması & $\begin{array}{c}\text { Çalışanlar } \\
(\%)\end{array}$ & $\begin{array}{c}\text { Uzmanlar } \\
(\%)\end{array}$ & $\begin{array}{l}\text { STK tem- } \\
\text { silcileri } \\
(\%)\end{array}$ & $\begin{array}{l}\text { İlgili kurum } \\
\text { temsilcileri } \\
(\%)\end{array}$ & $\begin{array}{c}\text { Genel } \\
\text { ortalama } \\
(\%)\end{array}$ \\
\hline 1 & $\begin{array}{l}\text { Mevcut örgütlenme ve yönetim yapısı gayet } \\
\text { uygundur }\end{array}$ & 11 & 0 & 3 & 3 & 4 \\
\hline 2 & $\begin{array}{l}\text { Bir bakanlığa veya Başbakanlık Müsteşar- } \\
\text { lığına bağlı merkezde tek Genel Müdürlük } \\
\text { (OGM) ve taşrada havza bazında örgütlen- } \\
\text { miş ormancılık birimleri ve güçlü Orman } \\
\text { İşletmesi }\end{array}$ & 31 & 33 & 22 & $\% 16$ & 25 \\
\hline 3 & $\begin{array}{l}\text { Müstakil bir Bakanlık ve bağlı Genel Müdür- } \\
\text { lükler ve taşrada havza bazında örgütlenmiş } \\
\text { OAGD birimleri ve bütün genel müdürlük- } \\
\text { lerin tek temsilcisi olarak güçlü bir Orman } \\
\text { İşletmesi }\end{array}$ & 32 & 34 & 43 & 41 & 38 \\
\hline 4 & $\begin{array}{l}\text { Müstakil bir Bakanlık ve bağlı Genel Müdür- } \\
\text { lükler ve taşrada havza bazında örgütlenmiş } \\
\text { OAGD birimleri ve her genel müdürlüğün } \\
\text { ayrı taşra birimleri }\end{array}$ & 20 & 21 & 19 & 31 & 23 \\
\hline & Diğer & 6 & 12 & 13 & 9 & 10 \\
\hline
\end{tabular}




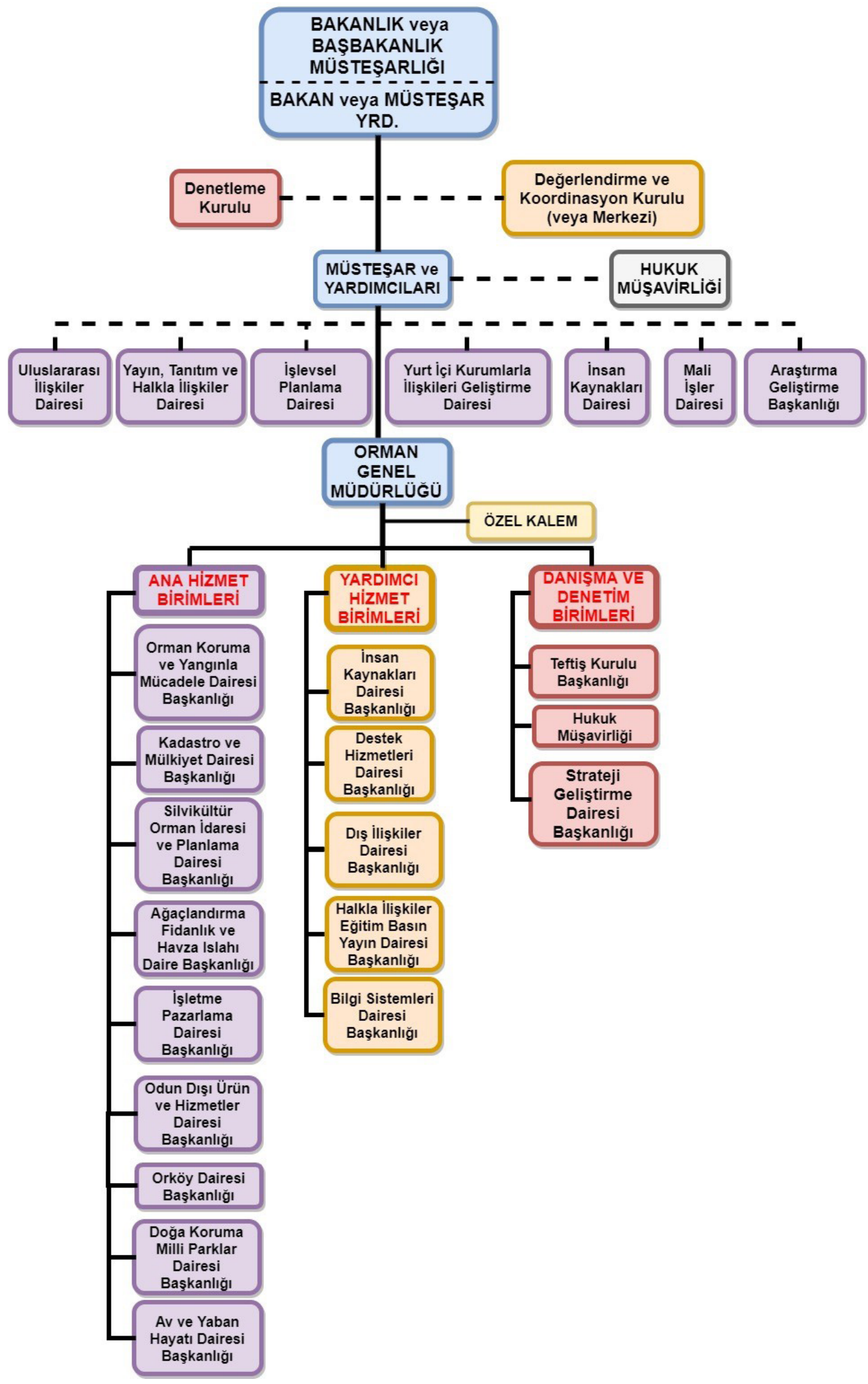

Şekil 1. Model-2’ye göre ormancılık örgütünün merkez yapılanması

Figure 1. The central structuring of the forestry organization according to model-2 
Çalışma kapsamında konuyla ilgili açık uçlu sorulara verilen yanıtlar, yapılan tüm değerlendirmeler ve daha önce yapılmış bazı çalışmalar (Daşdemir, 1999; Daşdemir, 2012; Daşdemir, 2016b; Anonim, 2015) dikkate alınarak, yukarıdaki alternatif örgütlenme ve yönetim modelleri ile bunların detayları aşağıda açıklanmıştır.

\subsubsection{Model-1: mevcut örgüt yapısı}

Denekler, “Türkiye'deki mevcut ormancllı örgütlenme ve yönetim yapısının uygunluğu” konusunda en az görüş birliği sağlamıştır (çalışanlar $\% 11$, uzmanlar \% 0, STK temsilcileri \% 3 ve ilgili kurum temsilcileri \% 3). Dolayısıyla, bu düşüncenin ilgi gruplarının büyük çoğunluğu (yaklaşık \% 96) tarafından kabul görmediği anlaşılmaktadır.

\subsubsection{Model-2'ye göre Ormancılık Örgütü}

Türkiye'deki ormancilık örgütlenmesi konusun$d a$ tüm ilgi grupları tarafından ortalama \% 25 ile ikinci sırada (çalışanlar \% 31, uzmanlar \% 33, STK temsilcileri \% 22 ve ilgili kurum temsilcileri \% 16) tercih edilen bir modeldir. Bu model göre herhangi bir bakanlığa veya Başbakanlık Müsteşarlığına bağlı tek Genel Müdürlük (OGM) ve taşrada havza bazında örgütlenmiş ormancılık birimleri ve güçlü Orman İşletmeleri şeklinde bir yapılanma öngörülmektedir (Tablo 19).

\subsubsection{Model-2'ye göre Ormancılık Örgütü merkez yapılanması}

Model-2’ye göre Ormancılık Örgütü'nün merkez yapılanması Şekil 1'deki gibi tasarlanmıştır. Buna göre; merkezde Bakanlığa bağlı Değerlendirme ve Koordinasyon Kurulu adında bir çalışma grubu oluşturulması gerekmektedir (Anonim, 2015). Bakanın başkanlık yapabileceği bu kurul, müsteşar, müsteşar yardımcıları ve bakanın belirleyeceği konularında uzman kişilerden oluşan bir yönetim kurulu şeklinde oluşturulmalıdır. Ormancılık kesimindeki kurul temsilcileri (genel müdür, işlevsel planlama dairesi, yayın tanıtım ve halkla ilişkiler dairesi, araştırma-geliştirme başkanlığ vb.) bu Yönetim Kuruluna karşı sorumlu olmalıdır. Yılda bir veya yılın belirli dönemlerinde toplanacak olan bu Kurula akademisyenler, ilgili STK ve kurumların temsilcileri de dahil edilmelidir. Böylece bu kurulda alınacak kararlar ve hazırlanan raporlar doğrultusunda, OGM yıllık programları ve gerçekleşmeleri, merkezde ve taşrada karşılaşılan problemler ve çözümleri, ormancılığın ileriye dönük politikaları ve amaçları tartışılır ve ülkemiz ormancılığının amaçlarına uygun yönetimi sağlanabilir.
Bakanlık merkezinde İşlevsel Planlama Dairesi adında bir birimin de oluşturulması gerekmektedir (Anonim, 2015). Zira orman kaynaklarının işlevsel planlaması ve haritalanması amenajman birimlerinden farklı bir konu olup "disiplinler arası bir ekibi ve çalışma düzenini” gerektirmektedir. $\mathrm{Bu}$ birimin ormanlık alanların makro düzeyde planlanmasından, üretim orman1, korunan alan, ağaçlandırma alanı, meralar vb. ayrılması, veri tabanlarının oluşturulması, ormanlık alanlarda arazi sinıflandirılması yapılması, ormanlık alanların göreceği işlevler bakımından sınıflandırılması gibi görevleri vardır. Bu şekilde orman amenajman heyetlerince yapılan hataların önüne geçileceği gibi, gündelik politikalar veya başka gerekçelerle yapılacak hatalar da önlenecektir. Zira Bakana bağlı Denetleme Kurulu söz konusudur. Bakanlık merkezinde ayrıca Uluslararası İlişikler Dairesi, Yurtiçi Kurumlarla İlişkileri Gelişstirme Dairesi, Insan Kaynakları Dairesi, Yayın, Tanıtım ve Halkla İlişikler Dairesi ile ormancılık araştırma ve geliştirme faaliyetlerinden sorumlu Araştırma-Geliştirme Başkanlığ maktadir.

Model-2'ye göre OGM merkez yapılanması; ana hizmet birimleri, yardımcı hizmet birimleri, danışma ve denetim birimlerinden oluşmaktadır. Buna göre ana hizmet birimleri arasında orman bakımı, gençleştirme, ormanların sürdürülebilir planlamas1, orman amenajman1, otlatma amenajmanı, yangın kontrolü planlaması, av hayvanları amenajman1, havza amenajmanı vb. faaliyetlerden sorumlu Silvikültür-Orman İdaresi ve Planlama Daire Başkanlığl adıyla bir birim düşünülmüştür. OGM merkez örgüt yapısında yer alan Strateji Geliştirme Dairesi Başkanlığının görevlerini taşrada yerine getirecek ormancılık birimleri bünyesinde Strateji Geliştirme Şube Müdürlüğ̈ kurulması gerekmektedir. Strateji Geliştirme Dairesi Başkanlığının yapmış olduğu her türlü çalışma ve planlamadan merkezden tabana kadar her birimin bilgi sahibi olması ve buna uygun hareket edilmesi gerekmektedir. Y1l içerisinde mevsimsel özellikler gösteren, yangınla mücadele ile süreklilik arz eden diğer koruma faaliyetlerinin bir biri ile doğrudan ilişkili olması ve etkin kaynak kullanımı nedeniyle, orman yangınlarıyla mücadele işleri ile orman zararlılar ile işleri OGM merkez yapılanmasında Orman Koruma ve Yangınla Mücadele Daire Başkanlığı adı altında bir birim bünyesinde toplanmıştır (Anonim, 2015).

Personelle ilgili iş ve işlemleri yürütmek ve performans ölçümleri yapmak üzere İnsan Kaynakları Dairesi Başkanlığı” düşünülmüştür. Halkın 
eğitimi, bilgilendirilmesi, katılımının sağlanması, güveninin kazanılması ve kamuoyu gereksinim ve tercihlerinin araştırılması amacıyla Halkla İlişkiler, Eğitim ve Basın Yayın Dairesi Başkanlığı; idari işler, taşınır kayıt ve kontrol işleri, genel evrak işleri, inşaat ve ikmal işleri, satın alma ve ihale işleri, arşiv işleri, bütçe ve tahakkuk işleri vb. ise Destek Hizmetleri Dairesi Başkanlığ bünyesinde toplanmıştır.

Sürdürülebilir havza yönetimi ve planlanmasına uygun olarak havza bazında, bütünleşik ve birbirlerini tamamlar nitelikte olan ağaçlandırma, fidanlik ve tohum işleri, toprak muhafaza ve havza islahı işlerini yürütmek üzere Ağaçlandırma, Fidanlık ve Havza Islahı Daire Başkanlığ $\breve{l}$ şeklinde bir birim tasarlanmıştır.

Ayrıca OGM merkez ana hizmet birimleri arasında orman içi av ve yaban hayatı, eko-turizm faaliyetleri, milli park, tabiat parkı, mesire yerleri, kent ormanları ve ağaç parkı gibi görevleri de bulunan Doğa Koruma ve Milli Parklar Dairesi Başkanlığl; avcılık, av hayvanları ve yaban hayati işlerinden sorumlu Av ve Yaban Hayatı Dairesi Başkanlığı; ormanlardan elde edilen odun dişı ürün ve hizmetlerden sorumlu Odun Dışı Ürün ve Hizmetler Daire Başkanlığı; orman köylerinin kalkındırılmasından sorumlu ORKÖY Dairesi Başkanlığı; ormanların kadastrosu ve mülkiyet işlerinden sorumlu Kadastro ve Mülkiyet Dairesi Başkanlığı; ormanların işletilmesi ve orman ürünlerinin pazarlanması işlerinden sorumlu İşletme Pazarlama Dairesi başkanlığ 1 bulunmaktadır.

\subsubsection{Model-2'ye göre Ormancılık Örgütü taşra yapılanması}

Model-2'ye göre Ormanc1lık Örgütü'nün taşradaki yapılanması aşağıdaki gibi üç başlık altında (Bölge yapılanması, İşletme yapılanması-1 ve İşletme yapılanması-2) açıklanmıştır:

\section{Ormancılık Örgütü’nün bölge yapılanması:} Genellikle aynı alanda ve bir bütünlük içerisinde yapılan ormancılık faaliyetleri, taşrada havza bazında tek bir Orman İdaresi çatısı altında yürütülmesi gerekmektedir. Böylece orman kaynaklarının bir bütünlük anlayışı içerisinde rasyonel yönetilmesi sağlanacak; çok başlılık, yetki-sorumluluk çatışması ortadan kalkacak, hızlı karar alma, uygulama ve verimlilik artışı sağlanacak, kaynaklar daha organize ve ekonomik bir şekilde kullanılabilecek ve havza bazında yöresel ihtiyaçların karşılanmasına öncelik verilebilecektir (Şekil 2).

Model-2'ye göre Ormancılık Örgütünün bölge yapılanmasi; homojen coğrafi bölgeler (havza) bazında kurulacak Doğa Koruma ve Orman Bölge Müdürlüğü şeklinde düşünülmektedir. Bunun için mevcut

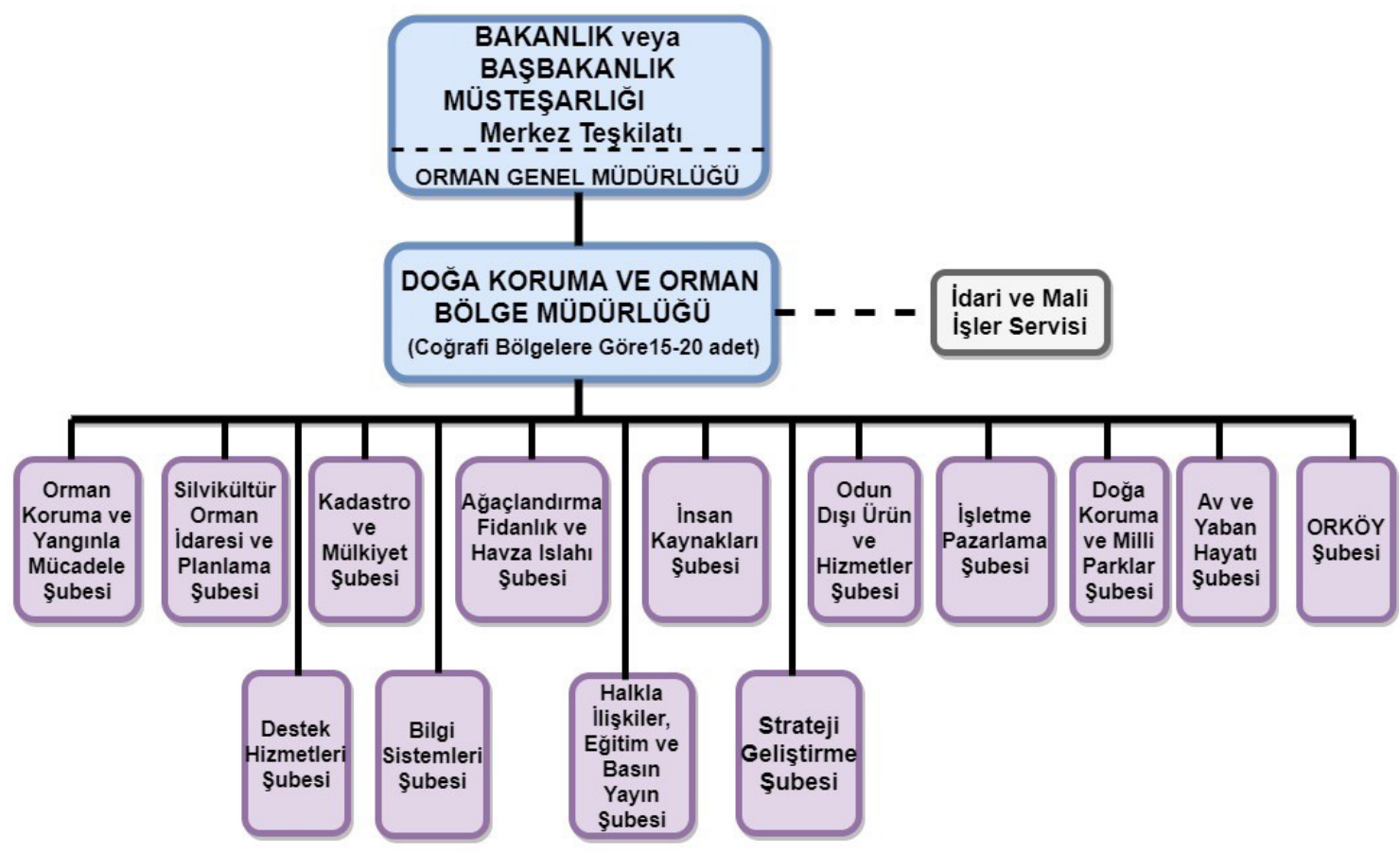

Şekil 2. Model-2'ye göre ormancılık örgütünün taşrada bölge yapılanması

Figure 2. The regional structuring of the forestry organization in the province according to model-2 


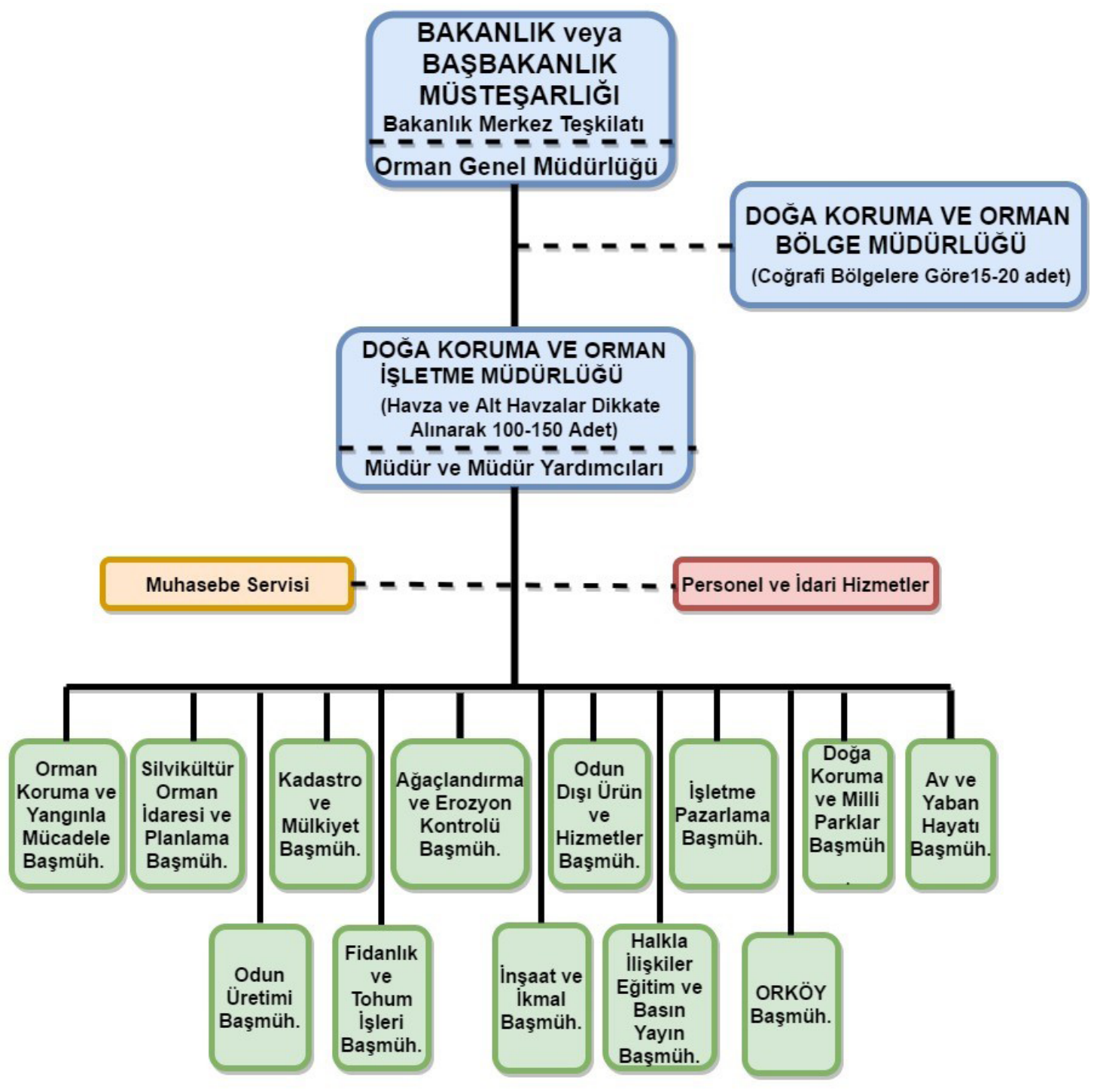

Şekil 3. Model-2'ye göre ormanc1lık örgütünün işletme müdürlüğü yapılanması (1)

Figure 3 . The structuring of the forest district directorate according to model-2 (1)

Orman Bölge Müdürlüklerinin hizmetleri, işlevleri ve coğrafi bölgelere dağılımı dikkate alınarak, sayılarının 15-20’ye düşürülmesi ve işlevlerinin yeniden gözden geçirilmesi gerekmektedir. Bölge müdürlükleri siyasi ve bürokratik bir makam olmaktan çıkartılarak, sadece bölgesindeki Orman İşletmeleri arasında eşgüdümü sağlayan, bilimsel ve teknik esaslara göre onları yönlendiren ve işlerin daha hızlı ve verimli yapılmasını sağlayan birimler haline getirilmesi daha uygun olacaktır. İş yoğunluğu ve öncelikli konular bölgeden bölgeye değişebilmektedir. Bölge Müdürlükleri, iş yoğunluğu ve öncelikli konulara göre dinamik bir halde yapılandırılmalı; personel sayısı azaltılmalı ve şube müdürlükleri OGM merkezindeki daire başkanlıklarına benzer şekilde, ama ihtiyaca ve iş yoğunluğuna göre oluşturulmalıdır. Doğa Koruma ve Orman Bölge Müdürlükleri daha çok planlama, denetim, danışmanlık ve yol gösterici rolü üstlenmelidir. Orman kadastro çalışmalarında sona gelindiği için, ihtiyaç olan bölgelerdekiler hariç, diğer bölgelerdeki Orman Kadastro Başmühendislikleri kaldırılmalı ve orman kadastrosunun (2/B ve tescil çalışmaları dahil) tamamı 3402 sayılı Kanun kapsamında yapılmalıdır.

2. Ormancılık Örgütünün taşrada İşletme yapılanması-1: Model-2'ye göre Ormancılık Örgütünün taşrada İşletme Müdürlüğü halinde yapılanması iki model halinde incelenmiştir. Birinci yapılanma modeli Şekil 3'te verilmiştir.

Modelde; taşrada bütün ormancılık faaliyetleri daha küçük alt havzalarda kurulacak ve sayıları 100-150 arasında değişen Doğa Koruma ve Orman 
İşletme Müdürlüğü (DKOİM) şeklinde tek çatı altında yapılandırılmaktadır. DKOİM işlerin hızlı, etkin ve verimli görülmesi, kaynakların rasyonel kullanımı ve amaçlara ulaşılması için konu temeline ve iş bölümüne dayalı başmühendislikler şeklinde alt birimleri ve her başmühendislikte yeteri kadar mühendis/şef ve uzman personeli bulunan, kendi başına sevk ve idare yeteneği olan birimlerdir. $\mathrm{Bu}$ birimlerin başında liyakate, deneyime ve bilgiye dayalı olarak sınavla atanmış müdür ile biri teknik işlerden, diğeri idari ve mali işlerden sorumlu olmak üzere iki müdür yardımcısı bulunmaktadır. Her bölgenin veya işletmenin koşulları, öncelikli konuları, iş yoğunluğu, amaçları, halkın talepleri ve ormancılığın gerekleri dikkate alınarak; odun üretimi, ağaçlandırma ve erozyon kontrolü, av ve yaban hayatı, işletme ve pazarlama, fidanlık ve tohum işleri, ORKÖY başmühendisliği gibi alt birimler, merkezdeki daire başkanlıklarına benzer şekilde, ancak ihtiyaca göre oluşturulmalıdır. Birim sorumlusu (Başmühendis) en deneyimli mühendis olma11, diğer mühendisler başmühendise karşı sorumlu olmalıdır. Her birimin sorumluluk alanı, İşletme Müdürlüğü’nün çalışma alanıyla sınırlandırılmalıdır; böylece İşletme Müdürlükleri güçlendirilerek, bütün personelin çalıştığı birimde uzmanlaşması ve yaptığı işe hakim olması sağlanacağından personelin hata yapma riski en aza inecektir. Uzman bir kadro ile yöresel koşullara uygun kararlar alma, uygulama ve başarılı olma şansı artacaktır.

3. Ormancılık Örgütünün taşrada İşletme yapılanması-2: Model-2'ye göre Ormancılık Örgütünün taşrada İşletme Müdürlüğü halinde ikinci yapılanmasına ilişkin model Şekil 4'te ve-

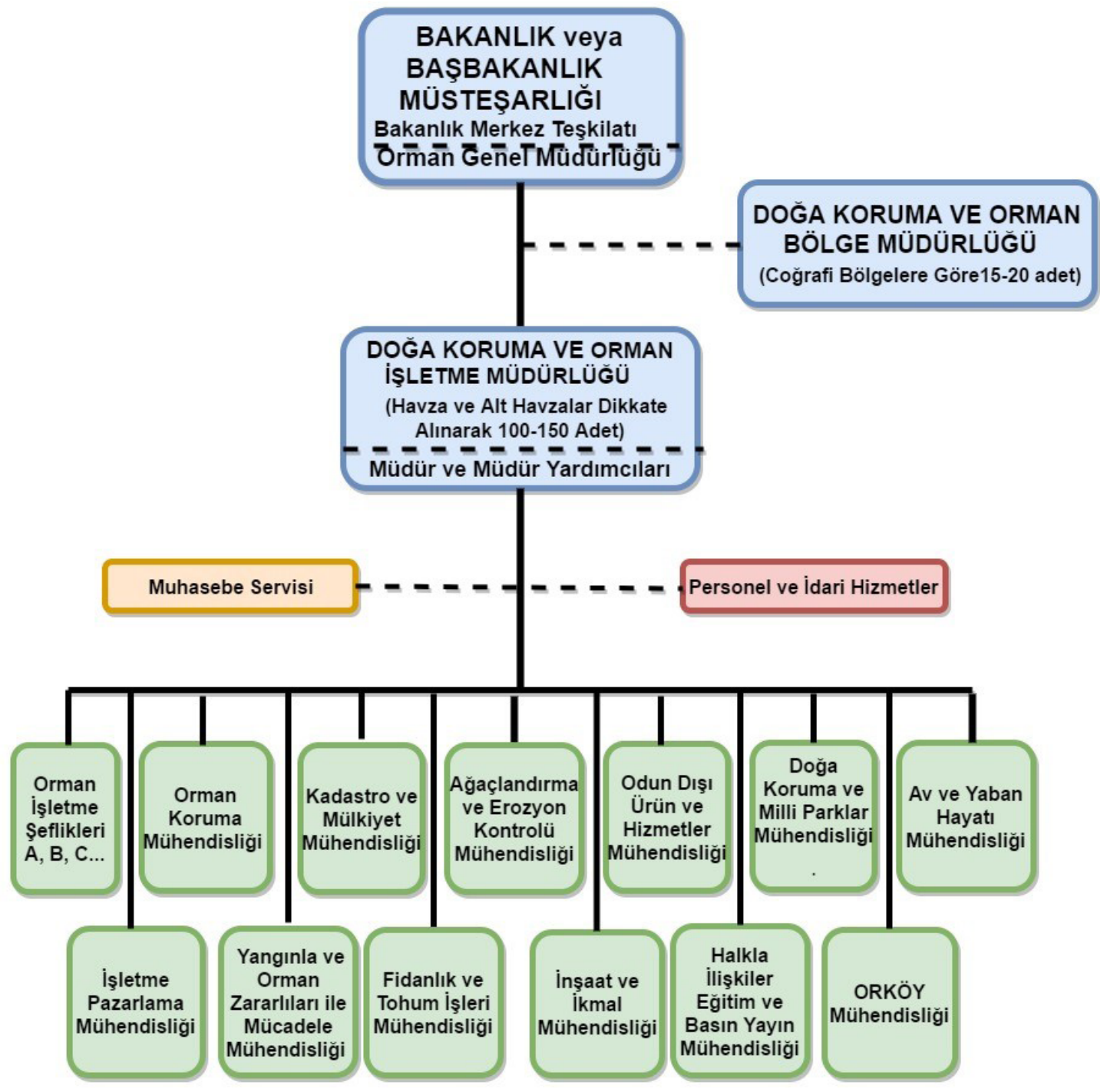

Şekil 4. Model-2’ye göre ormancılık örgütü işletme müdürlüğü yapılanması (2)

Figure 4 . The structuring of the forest district directorate according to model-2 (2) 
rilmiş olup, modelde Müdürlük alt birimleri olarak Mühendislikler ve Orman İşletme Şeflikleri söz konusudur. Müdürlüğün tamamını ilgilendiren konularda, iş yoğunluğuna, önceliklerine ve ihtiyaca göre korunan alanlar ve milli parklar mühendisliği, av ve yaban hayatı mühendisliği, üretim ve pazarlama mühendisliği, inşaat ve ikmal mühendisliği, fidanlık ve tohum işleri mühendisliği, halkla ilişkiler eğitim ve basın yayın mühendisliği, ORKÖY mühendisliği gibi birimler kurulabilecektir. İşletme Müdürlüğü çeşitli hizmet gruplarında (koruma, üretim, silvikültür, inşaat, pazarlama, mülkiyet ve izin vb.) uzman mühendisleri bulunduracağı için personel açısından güçlü bir yapıya kavuşacaktır (Anonim, 2002). Bu yapılanmada İşletme Şeflikleri plan ünitesinin alan sorumlusu olarak görev yapacak ve şeflikte ihtiyaca göre birden fazla teknik eleman çalışabilecektir. Teknik elemanlardan en tecrübelisi işletme şefi olarak, diğerleri ise onun emrinde teknik eleman olarak görev yapacak ve böylece genç mühendislerin uzmanlaşması sağlanacaktır.

\subsubsection{Model-2'ye göre Ormancılık Araştırma Enstitüleri}

Model-2'ye göre ormancılık araştırma faaliyetleri Bakanlık Araştırma-Geliştirme Başkanlığı'na bağlıdır; taşrada ise kuruluşları ve faaliyetleri bölgesel özelliklere ya da konu temeline dayalı olarak belirlenmiş birimler (Enstitüler) olarak düşünülmüştür (Şekil 5).

Merkezde araştırma faaliyetlerini ve Enstitüleri organize edecek, proje süreçleri ile resmi işlemleri takip edecek ve araştırma sonuçlarını tamim haline getirecek Bakanlık Araştırma-Geliştirme Başkanlı ̆gl oluşturulmuştur. Ormancılık Araştırma Enstitüleri çalışma alanının/konunun özelliklerine göre uzmanlıklara dayalı alt bölümlerden oluşmakta ve her bölümde yetkin ve deneyimli araştırmac1lar görev almaktadır. Enstitüler, uygulamayla iç içe çalışarak ve ormancılık problemlerini bilimsel yoldan çözerek bölge ve işletme müdürlüklerinin çalışmalarına olumlu katkı sağlayacak, onlara yol gösterecektir. Araştırma sonuçları Araştırma-Ge-

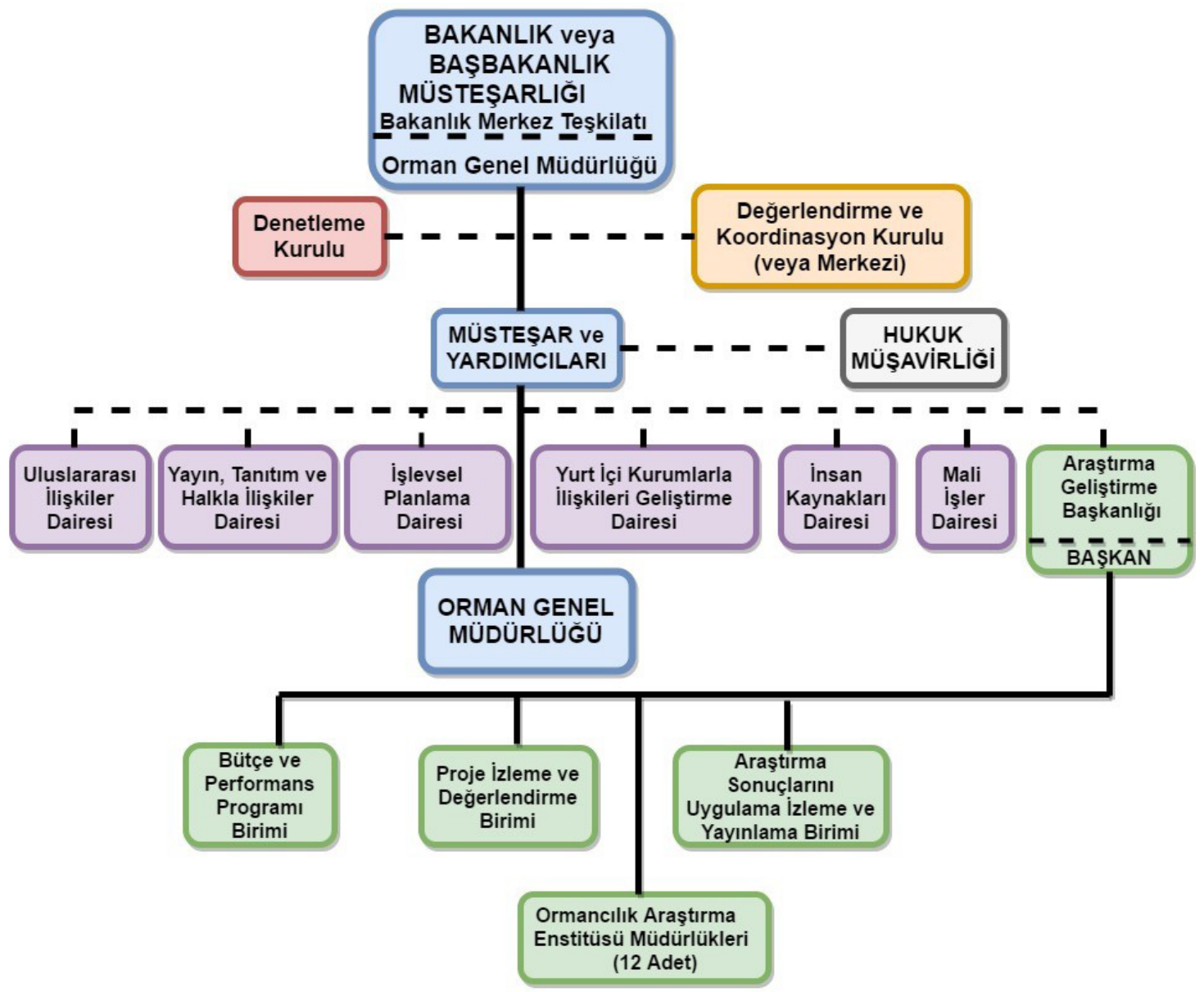

Şekil 5. Model-2'ye göre ormancılık araștırma enstitülerinin yapılanması

Figure 5. The structuring of the forestry research institutes according to model-2 
liştirme Başkanlığı aracılığıyla uygulamaya aktarılacağı için, daha güçlü ve etkili bir yapı olacaktır.

\subsubsection{Model-3'e göre Ormancılık Örgütünün yapılanması}

Tüm ilgi grupları tarafından ortalama \% 38 ile ilk sırada tercih edilen (çalışanlar \% 32, uzmanlar \% 34 , STK temsilcileri \% 43 ve ilgili kurum temsilcileri \% 41) örgütlenme modelidir (Şekil 6). Modele göre; merkezde müstakil bir Orman Bakanlığına bağlı farklı Genel Müdürlükler ve taşrada havza bazında örgütlenmiş bölgesel Ormancılık Araştırma-Geliştirme ve Denetleme Birimleri (OAGD) ile bütün Genel Müdürlüklerin tek temsilcisi olarak güçlü bir Ormancılık İşletmesi yer almaktadır (Tablo 19). Genel yapısı Şekil 6'da verilen ormancılık örgüt yapısı ve yönetim modelinin merkez ve taşra birimleri ve yapılanmaları, görev yetki ve sorumlukları, çalışma usul ve esasları aşağıdaki gibidir (Daşdemir, 1999; Daşdemir, 2012; Daşdemir 2016b).

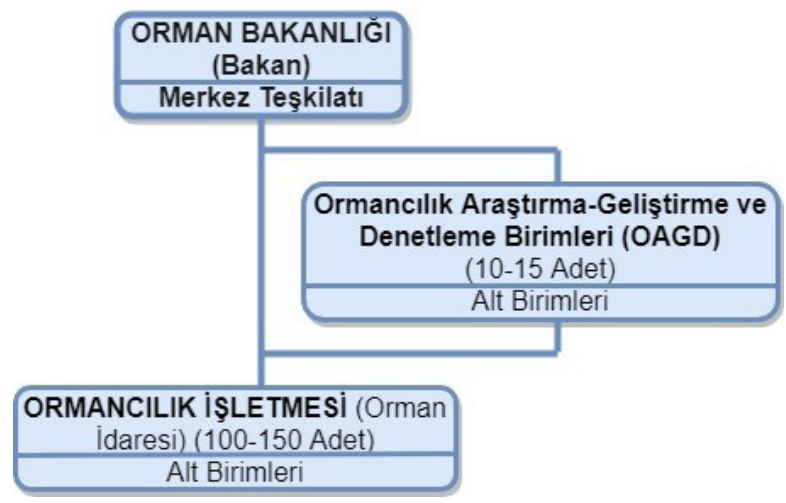

Şekil 6. Model-3'e göre ormanc1lık örgütünün genel yapıs1

Figure 6 . The general structure of the forestry organization according to model-3

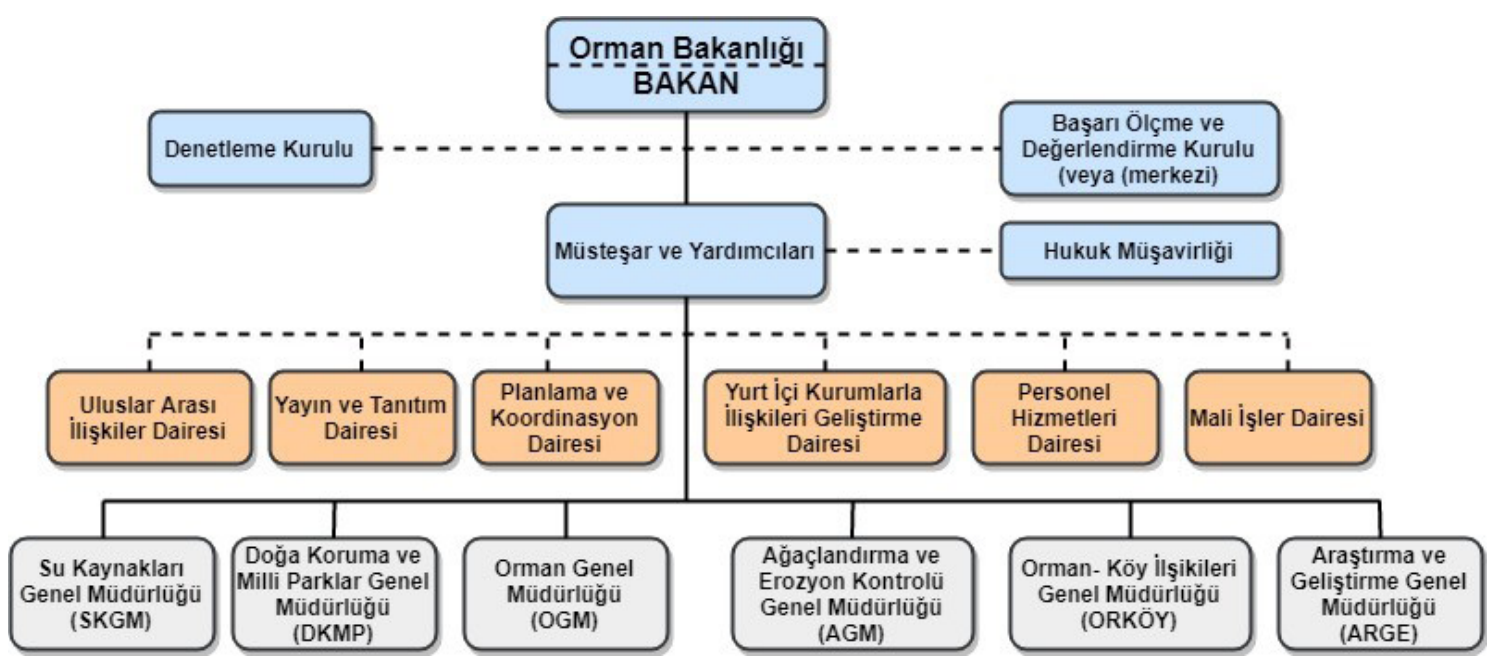

Şekil 7. Model-3'e göre ormancılık örgütünün merkez yapılanması

Figure 7. The central structuring of the forestry organization according to model-3

\subsubsection{Model-3’e göre Ormancılık Örgütünün merkez yapılanması}

Modele göre; Ormancılık Örgütü merkezde ayrı bir siyasi karar birimi, yani Orman Bakanlığ düzeyindedir. Bakanlık ana hizmet birimleri, yardimcı hizmet birimleri, demokratik esas ve usullere göre çalışan birtakım kurulları, Başarı Ölçme ve Değerlendirme Merkezi ile bağlı birimlerinden oluşur. Merkez teşkilatında ayrıca genel müdürlükler (OGM, AGM, DKMP, ORKÖY, ARGE ve SKGM) yer alır (Şekil 7). Modeldeki ARGE ve SKGM şimdiye kadarki tüm Orman Teşkilatlanması için yeni bir teklif olup, bilime, araştırmaya ve su kaynaklarının yönetimine önem verildiğini göstermektedir. Keza merkez birimlerinin ihtiyaca göre alt birimleri vardır. Merkez teşkilatı, faaliyet alanına giren konularda Bakanlığa danışma- 
lık yapan, ormancılık politikasını ve amaçlarını saptayan, taşra örgütünü amaçlar doğrultusunda yönlendiren, onların çalışmalarına yardımcı olan, işbirliğini ve koordinasyonu sağlayan, başarılarını ölçen ve değerlendiren, sonuçlarını kamuoyuna açıklayan, makro düzeydeki birimlerdir. Merkez teşkilatında her birimin yöneticileri konularında uzman olup, bunlar merkez birimlerin, bölgesel ormancılık birimlerinin ve ormancılık işletmelerinin yetkililerinin katılımıyla yapılacak seçimler sonucuna veya yapılacak objektif sınavlara göre atanmalıdır. Merkez birimleri kararlarını oy çokluğu ile alır, katılımcı, demokratik ve özerktir.

\subsubsection{Model-3'e göre Ormancılık Örgütünün taşra yapılanması}

Model-3'e göre Ormancıllk Örgütüne ait taşra yapılanması; 1) Bölge yapılanması, 2) İşletme yapılanması şeklinde aşağıdaki gibi açıklanmıştır:

1. Ormancılık Örgütünün taşrada Bölge yapılanması: Model-3'e göre Ormancılık Örgütüne ait Bölge yapılanması, mevcut Orman Bölge Müdürlüklerinin Ormancılık Araştırma Enstitüleriyle birleştirilmesiyle homojen havzalarda (bölgelerde) kurulacak Ormancılık Araştırma-Geliştirme ve Denetleme (OAGD) birimleri şeklinde tasarlanmıştır. Fiziksel, teknik, sosyal, yönetsel ve işlevsel değişkenler göz önünde tutularak yapılacak analizler sonucunda bunların yerleri, faaliyet alanları ve sayıları (10-15 olabilir) belirlenmelidir (Şekil 8).

OAGD birimleri; bölgelerindeki İşletmelerin faaliyetlerini etkin şekilde yerine getirmelerine yardımc1 olan, proje üreten, inceleme ve araştırma yapan, sonuçlarını uygulamaya aktaran, danışmanlık yapan, çalışanları eğiten, bölgesel planlar ve programlar hazırlayan, işletmelerin faaliyetlerini denetleyen, işletmelerin yıllık faaliyet sonuçlarını Orman Bakanlığı merkezindeki Başarl Ölçme ve Değerlendirme Merkezine bildirmekle sorumlu ve merkez ile İşletmeler arasındaki koordinasyonu sağlayan organik üst kuruluşlardır. OAGD'lerin örgüt yapısı ve alt birimleri (şubeleri), her bölgenin özelliklerine ve gereklerine göre

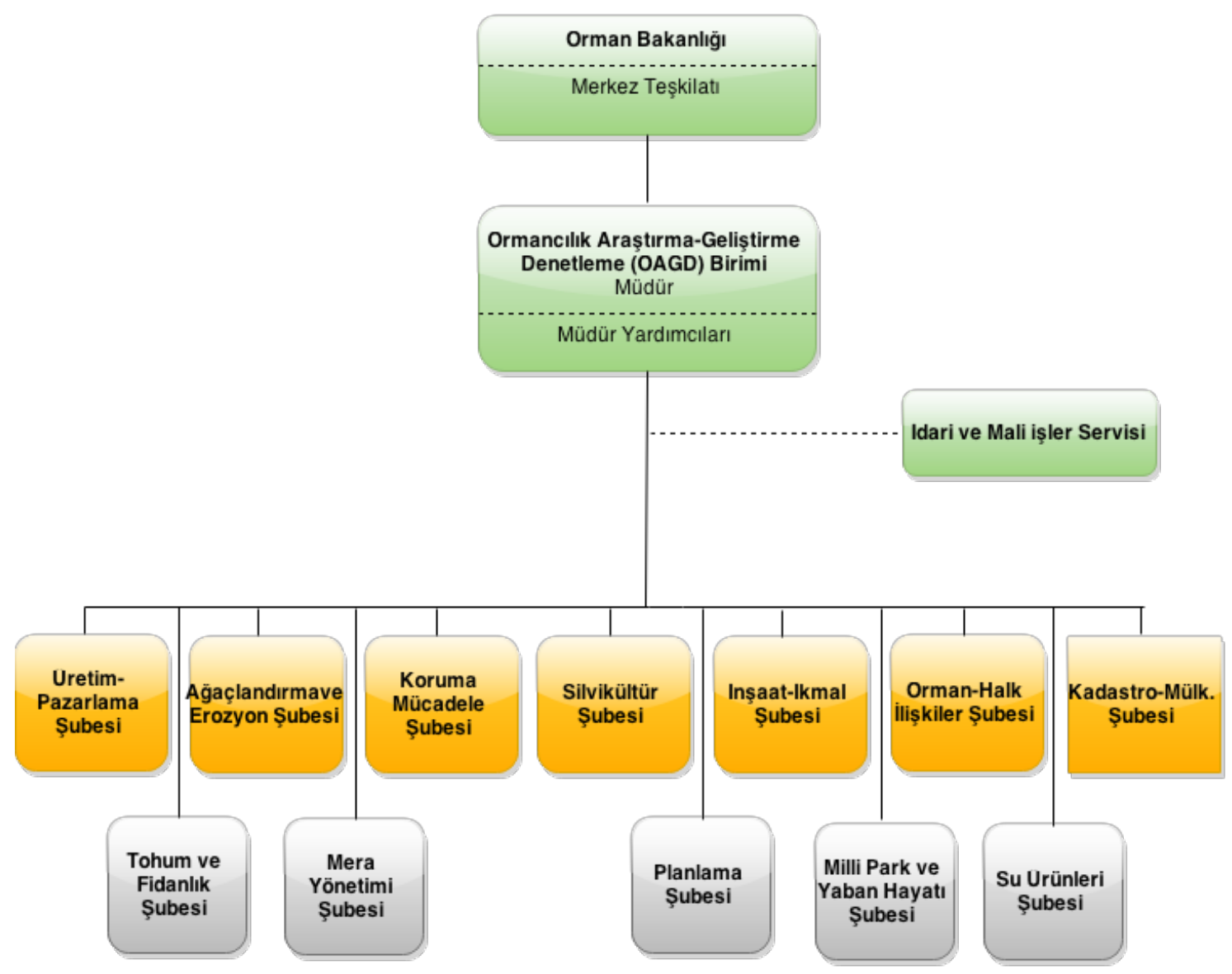

Şekil 8. Model-3'e göre ormancılık örgünün taşrada bölge yapılanması

Figure 8 . The regional structuring of the forestry organization in the provinces according to model-3 
şekillendirilmelidir. Bunların yönetim sistemi, tamamen demokratik ilkelere ve objektif kriterlere dayalı olup, çalışmayı, uzmanlığ 1 , araştırmayı ve bilimi öne çıkaran, yerinden ve özerk yönetimi esas alır. OAGD yöneticileri, şube temsilcilerinin katılımıyla yapılacak seçimle belirlenir. Şube temsilcileri ise objektif sınavlarla atanır.

2. Ormancılık Örgütünün taşrada İşletme yapılanması: Model-3'e göre Ormanc1lık Örgütünde en altta yer alan Ormancılık $\dot{I}_{\text {şletmeleri }}$ işleri yürüten, idari açıdan merkeze bağlı, ancak araştırma, geliştirme ve denetleme faaliyetleri bakımından ise organik olarak OAGD birimleri ile uyumlu çalışan, mahalli koşullara göre kurulmuş, yetki ve sorumluluğu kendisine ait özerk birimlerdir (Şekil 9). Ormancılık İşletmesine bağlı olarak çalışan, işi yürüten ve uzmanı olan işletme, $p a$ zarlama, ağaçlandırma, erozyon kontrolü, mera yönetimi, silvikültür, tohum ve fidanlık, koruma, ORKÖY, milli park-yaban hayatı, inşaat vb. gibi Başmühendislikler vardır. Bunların sayısı ve işlevleri, orman kaynaklarının özellikleri, İşletmenin amaçları, bölgenin sosyoekonomik yapısı ve diğer faktörler dikkate alınarak, her İşletme için ayrı ayrı belirlenir. Bunlar, havza bazında örgütlenmiş OAGD'lerin çalışma alanlarında daha mikro düzeyde homojen alanlarda kurulacak olan ve sayıları 100-150 adet olması beklenen birimlerdir.

Ormancılık İşletmesi bünyesinde belirli aralıkla toplanan ve bir nevi kılavuzluk eden Danışma ve Değerlendirme (Yönetim) Kurulu bulunmaktadır (Şekil 9). Kurul başkanı İşletme müdürüdür; üyeleri ise müdür yardımcıları, başmühendisler, muhasebeci, personel şefi, orman köylerinin muhtarları, ormancılık kooperatiflerinin başkanları, kamu kurum-kuruluş ve yerel yönetim yetkilileri, sivil toplum ve özel sektör temsilcileridir. Kurulda hem işletmenin işlevsel ve yönetsel faaliyetleri tartışılmakta, hem de İşletme faaliyetleri hakkında kamuoyuna bilgi verilmekte ve toplumsal talepler dikkate alınmaktadır. Yani bu kurul, İşletmenin amaçlarına ulaşması ve başarılı olmasına yol gösterir. Karşılaşılan sorunların araştırılması, bilimsel yoldan çözülmesi sağlanacak ve dolayısıyla araştırmaya, bilime ve bilgiye talepçi olunacaktır.

Araştırmayı, bilgiyi-beceriyi, uzmanlığı ve deneyimi öne çıkaran, katılımcı, demokratik ve yerinden yönetimi esas alan bu özerk örgüt yapısında İşletme yöneticileri (müdür ve müdür yardımcıları) politikayla değil, deneyimli, çalışkan, onursal değerleri yüksek, bilgili, becerikli, sosyal ilişkileri iyi, yabancı dil bilen, sevk ve idare kabiliyeti olan Orman Mühendisleri arasından sınavla atanmalı ve elemanlarını seçme (atama, yer değiştirme vb.) yetkileri olmalıdır. Önerilen örgütlenme modelinde emir-komuta zinciri keskin bir şekilde işletilmeyip, yetki ve sorumluluk Ormancılık İşletmelerine bırakılmaktadır. Ormancılık İşletmelerine verile-

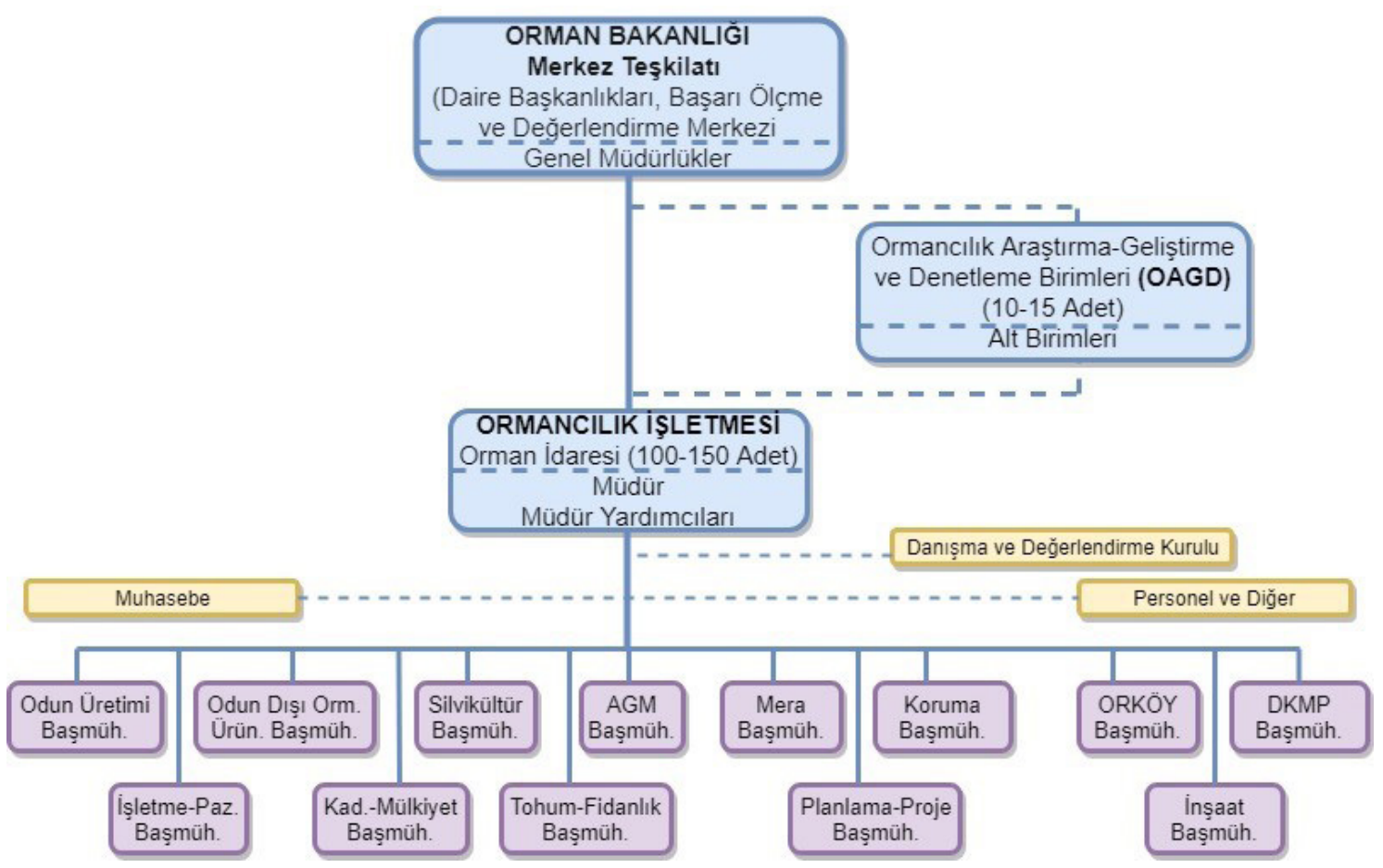

Şekil 9. Model-3'e göre taşrada orman işletmesinin yapılanması

Figure 9. The structuring of the sub-district forest units in the provinces according to model-3 
cek özerklik, İşletme Müdürlüklerinin yetki ve sorumlulukları artırılarak, onları nihai karar birimleri yapma anlamındadır. Özerk örgüt yapısının gereği olarak, İşletmelerin yıllık başarıları Bakanlık Başarı Ölçme ve Değerlendirme Merkezi tarafından ölçülmeli ve çalışanlara başarı oranlar1na göre prim verilmelidir.

\subsubsection{Model-4'e göre Ormancılık Örgütünün yapılanması}

Deneklerin ortalama \% 23'ünün (çalışanlar \% 20, uzmanlar \% 21, STK temsilcileri \% 19 ve kurum temsilcileri \% 31) görüşlerini yansitan bu model; merkezde müstakil Bakanlığa ait farklı Genel Müdürlükler, taşrada ise havza bazında örgütlenmiş bölgesel OAGD birimleri ve her genel müdürlügün ayrı taşra birimlerinden oluşur (Tablo 19). Modelde; Ormancılık Örgütünün merkez ve bölge yapılanması Model-3'teki gibi tasarlanmış olup, Model-3'teki merkez ve bölge yapılanması şemaları Model-4 için de geçerlidir (Şekil 7 ve 8). Ancak Model-3'ten farklı olarak Model-4'te taşrada havza bazında mikro düzeyde homojen alanlarda bütün genel müdürlüklerin temsilcisi olacak tek bir Ormancılık İşletmesi yerine, merkezdeki her genel müdürlüğün ayrı taşra birimleri şeklinde örgütlenmesi öngörülmektedir.

\section{Tartışma ve Sonuç}

Türkiye'de Ormancılık Örgütünün sorunlarından hareketle alternatif örgütlenme modellerinin geliştirilmesi amacıyla ele alınan bu çalışmada; çağdaş ormancılık anlayışına ve ormancılıkta kabul gören yönetim ve örgütlenme ilkelerine uygun olarak Türkiye ormancılığı için alternatif örgütlenme modelleri ve yönetim anlayışları geliştirilmiş ve öncelikleri belirlenmiştir.

Pek çok ormancılık çalışmaları birlikte ve aynı alanda yapıldığından, yetki-sorumluluk çatışmasına neden olunmaması ve işlerin daha hızlı ve verimli yürümesi açısından, deneklerin büyük çoğunluğu Ormancılık Örgütünün gerek merkezde ve gerekse taşrada ayrı birimler halinde değil de, tek bir birimle (OGM) temsil edilmesi ve işlerin tek bir birimle yürütülmesi gerektiği görüşündedir. Ayrıca taşra birimleri olmayan ÇEM'in merkez örgütlenmesinin başarılı olmayacağı, daha çok Ar-Ge işiyle uğraştığ 1 ve bu işin de Ar-Ge birimlerince yapılmasının uygun olduğu sonuçlarına varılmıştır.

Ormanc1lık örgütlenmesi ve yönetimiyle ilgili dört farklı modelin sonuçları topluca değerlendirildiğinde; merkezde ayrı Genel Müdürlükler veya tek genel müdürlük (OGM) şeklinde ortaya çıkan iki farklı yapılanma, model tercihini veya önceliğini belirlemede fazla etkili değilken, taşrada Bölge ve İşletme yapılanması model tercihi üzerinde daha fazla etkilidir. Özellikle ormancılık faaliyetlerinin taşrada homojen havzalar bazında ve bir bütünlük içerisinde tek bir ormancılık birimi tarafından yürütülmesi en çok tercih edilen yaklaşım olmuştur.

Ormancılığın Bölge yapılanması ile ilgili üç farkl1 yapılanma ortaya çıkmıştır: Birincisi; dört ilgi grubunun en az tercih etmiş olduğu mevcut bölgesel yapının (OSİB Bölge Müdürlükleri ve Orman Bölge Müdürlükleri,) devamıdır. Ancak, bu düşünce deneklerin büyük çoğunluğu tarafından (yaklaşık \%90) kabul görmemiştir. İkincisi; ormancılık faaliyetlerinin taşrada bölgesel bazlı tek bir birim tarafından yürütülmesi ve temsil edilmesidir. $\mathrm{Bu}$ yapılanma denekler tarafindan en fazla kabul edilen modeldir. Bunda ise iki farklı alternatif söz konusudur. İlki, ormancılık faaliyetlerinin işlevlere ve coğrafi bölgelere dayalı olarak havza bazında kurulacak Doğa Koruma ve Orman Bölge Müdürlüğ̈ü birimlerince yürütülmesidir. İkincisi, Orman Bölge Müdürlükleri ve Ormancılık Araştırma Enstitüleri birleştirilip, homojen havzalarda (bölgelerde) Ormancılık Araştırma-Geliştirme ve Denetleme (OAGD) birimlerinin oluşturulmasıdır. Üçüncüsü ise her Genel Müdürlüğün taşrada ayrı bölge yapılanmalarına sahip olmalarıdır. Ancak bölgesel yapılanmada, ormancılık faaliyetlerinin tek birimce yürütülmesini esas alan Model-3 (\% 38) ve Model-2 ( $\%$ 25) örgütlenme ve yönetim yapılanması daha çok tercih edilmiştir.

Ormancılık Örgütünün taşrada İşletme Müdürlüğü yapılanması ile ilgili olarak da dört farklı alternatif vardır. İlki, deneklerin büyük çoğunluğunun (yaklaşık \% 96) en az tercih ettiği ve işleyişinde büyük sorunların olduğu kabul edilen mevcut yapının devamıdır. İkincisi, Orman İşletme Şeflikleri kaldırılarak, merkezdeki Daire Başkanlıklarına benzer yapının Bölge Müdürlükleri ve İşletme Müdürlüklerinde de kurulmasıdır. Üçüncüsü, mevcut Orman İşletme Şefliklerinin, plan ünitesinin alan sorumlusu olarak göreve devam etmeleri, ancak İşletme bütünlüğünü ilgilendiren ve uzmanlık gerektiren konularda Mühendislikler şeklinde yeni birimlerin kurulmasıdır. Dördüncüsü ise mikro havzalar bazında kurulmuş ve ihtiyaca göre Başmühendislikleri olan, bilgiyi, uzmanlığı, katılımcılığ mokratik ve yerinden yönetimi esas alan, yetki ve sorumluluğu kendisine ait olan, başarıyı motivasyon ve objektif ölçütlere göre ölçen özerk yapıdaki güçlü Ormancılık İşletmeleridir. Ancak dördüncü alternatif (Model-3) denekler tarafindan en çok tercih edilmiştir. Bu çalışmada Türkiye ormanc1lığı için dört farklı örgütlenme ve yönetim modeli 
(Model-1, Model-2, Model-3 ve Model-4) deneklerin görüşüne genel hatlarıyla sunulmuş (Tablo 19); anketler, analizler ve değerlendirmelere göre modellerin detayları oluşturulmuştur. Buna göre; Model-1: Mevcut örgütlenme ve yönetim yapısıdır ve deneklerin yaklaşık \%90'1 tarafından kabul görmemiştir. Model-2: Herhangi bir Bakanlı̆̆a veya Başbakanlık Müsteşarlı̆̆ına bağll merkezde tek Genel Müdürlük (OGM) ve taşrada havza bazında örgütlenmiş ormancılık birimleri ve güçlü Orman İşletmeleri şeklinde olup, deneklerin tarafından ortalama $\% 25$ ile ikinci derecede tercih edilen modeldir. Model-3: Merkezde müstakil bir Bakanlık ve bağlı Genel Müdürlükler ve taşrada havza bazında örgütlenmiş Ormancılık Araştırma-Geliştirme ve Denetleme (OAGD) birimleri ve bütün genel müdürlüklerin tek temsilcisi olarak güçlü $O r$ mancılık İşletmeleri şeklindeki yapılanmadır ve denekler tarafından ortalama \% 38 ile en çok tercih edilen modeldir. Model-4: Merkezde müstakil Bakanlık ve bağll Genel Müdürlükler ve taşrada havza bazında örgütlenmiş OAGD birimleri ve her genel müdürlüğün ayrı taşra birimleri şeklindeki yapılanmadır ki denekler tarafından ortalama \%23 ile üçüncü sırada tercih edilmiştir.

$\mathrm{Bu}$ sonuçlara göre, birinci öncelikle tercih edilen Model-3 ve ikinci öncelikle tercih edilen Model-2 birlikte değerlendirildiğinde; her iki modelde de ormancılık faaliyetlerinin taşrada havza bazlı Bölge ve İşletme şeklinde tek bir birim tarafından yürütülmesi gerektiği sonucuna varılmaktadır. Ayrıca her iki modelde de en çok kabul gördüğü tespit edilen; teknik ve bilimsel çalışma, işbölümü ve uzmanlaşma, demokratiklik, katılımcılık, verimlilik ve üretkenlik, bütünleşik yönetim ve eşgüdüm, özerklik, yetki devri ve sorumluluk, sosyal sorumluluk, yöresellik, rekabet ve motivasyon ilkelerine uygun örgütlenme ve yönetim anlayışı görülmektedir. Model-3 yaşama geçirilirse aşağıdaki faydaların sağlanacağı düşünülmektedir;

1. Orman kaynaklarının havza bazında ve bir bütünlük anlayışı içerisinde rasyonel, katılımcı, demokratik ve yerinden yönetimi sağlanır.

2. Uygulayıcı birimler arasında olumlu rekabet ortamı yaratılarak, ormancılık faaliyetlerinin ekonomik, teknik ve bilimsel temellere dayalı yürütülmesi sağlanır.

3. Bilginin, uzmanlığın, iş bölümünün ve araştırmanın öne çıkması, uygulayıcı birimlerin araştırmaya ve bilime talepçi kuruluşlar haline getirilmesi, araştırma-uygulama işbirliğinin sağlanması ve araştırma sonuçlarının uygulamaya aktarılması sağlanır.
4. Liyakate dayalı başarı tanımı ve kriterleri belirlenir, başarı objektif ve çok boyutlu ölçülür.

5. Performansa dayalı bir sistem söz konusu olduğu için iş verimliliği ve başarı artar.

6. Merkezi kararlar ve politik baskılar dışlanarak, yöresel koşullara uygun kararlar verilir.

7. İşletme bazında uzmanlık ve kadrolaşma olacağ1 için personelin tabana yayılması ve adil bir personel politikasının izlenmesi sağlanır.

8. Ormancılığımızın bir sistem olarak işlemesi, sorunlarının giderilmesi, çağdaş ormancılık anlayışının hakim kılınması ve böylece ormancılığın saygınlık kazanması ve dinamik bir yapıya kavuşması sağlanır.

Model-2'nin yaşama geçirilmesi halinde ise aşağıdaki faydaların sağlanacağı düşünülmektedir;

1. Orman kaynaklarının bir bütünlük anlayışı içerisinde rasyonel yönetilmesi sağlanır, çok başlılık, yetki-sorumluluk çatışması ortadan kalkar.

2. Kurum fiziksel ve beşeri imkanlarını daha etkin ve ekonomik olarak kullanabilir.

3. Her yörenin havza bazında kendi ihtiyaçlarına öncelik verilir.

4. İş ve işlemlerde hızlı karar alma, uygulama ve verimlilik sağlanır.

5. Planlama, yürütme, denetim ve eşgüdüm sorunlarının azalması, böylece motivasyonun, üretimin, verimliliğin ve başarının artması sağlanır.

6. Orman Bölge Müdürlüklerinin koordinasyon, danışma ve denetim birimleri olarak hizmet vermeleri sağlanır.

7. Uzmanlaşma ve branşlaşma İşletme Müdürlükleri/ Şeflikleri bünyesinde sağlanır.

8. Teknik elemanlar belirli konularda görev yapıp, uzmanlaştığı için hata riski azalır.

9. İşletme Şeflerinin aşırı görev ve sorumlulukları ve böylece personel devir hızı azalır.

10. Teknik ve yönetsel personel uzmanlıkrına uygun işlerde çalışacağı için fazla çalışma zorunlulukları en aza iner.

Genel hatları bu çalışmada verilen alternatif örgütlenme ve yönetim modellerinde;

1. Türkiye için önem arz eden özellikle kadastro, orman yangınlarl, planlama, denetim, başarı 
ölçümü ve Ar-Ge çalışmalarıyla ile ilgili birimlerin, etkili ve verimli hizmet vermelerini sağlayacak şekilde modellerde yer alması gerekmektedir.

2. Orman kadastro çalışmaları, gelişmiş ülkelerdeki gibi tek bir birim (Tapu ve Kadastro Genel Müdürlüğü) eliyle yürütülmelidir.

3. Orman yangınlarıyla mücadelede mevcut sistem başarılı olmasına rağmen, yangın çıkmadan önleme tedbirlerini ön planda tutan stratejiler benimsenmelidir.

4. Ormanların planlamasında yöresel önceliklere ve coğrafi bölgelerin özelliklerine göre katılımcılık esaslı ve uzman kişilerden oluşan Amenajman Başmühendisliklerinin kurulmasına önem verilmelidir.

5. Ormancılık çalışmaları, özellikle araştırma ve denetleme birimleri siyasi baskılardan uzak ve özerk yapılı birimlerce yürütülecek yapıya sahip olmalıdır.

Türkiye ormancılığı için söz konusu alternatif örgütlenme ve yönetim modelleri burada sadece ana hatları ile verilmiştir. Modellere ait detaylar, yani birimlerin adları, sayıları, yerleri, görev, yetki ve sorumlulukları, çalışma usul ve esasları, denetim ve başarı ölçüm süreçleri ve dolayısıyla örgüt k1lavuzları her bir modelin ana felsefesine uygun olarak yapılacak ayrıntılı çalışmalarla ortaya konulabilecek hususlardır.

\section{Teșekkür}

Bu çalışma OGM'ce desteklenen ve Marmara Ormancılık Araştırma Enstitüsü Müdürlüğü tarafından yürütülen "Türkiye Ormancılığı İçin Alternatif Örgütlenme Modellerinin Geliştirilmesi" adlı ve 10.5301/2014-2017 numaralı araştırma projesi kapsamında üretilmiştir.

\section{Kaynaklar}

Akesen, A., 2005. I. Çevre Şurasının Ardından. Orman Mühendisliği Dergisi, Y11 42, Say1 4-5-6, s.3

Akesen, A., Ekizoğlu, A., Erdönmez, C., 2007. Küreselleşme Sürecinde Türkiye Ormancıllk Politikası. Orman Kaynaklarının İşlevleri Kapsamında Darboğazlar, Çözüm Önerileri ve Öncelikler: Türkiye'de Ormancılık Eğitiminin 150. Yllında Uluslararast Sempozyum, 17-19 Ekim, s.417-4236, İstanbul

Anonim, 2002. TC Orman Genel Müdürlüğü Yeniden Yapılanma ve Norm Kadro Projesi, Cilt: 3, Önerilen Yap1 Son Rapor, Merkez ve Taşra Teşkilatı, Türkiye ve
Orta Doğu Amme İdaresi Enstitüsü (TODAİE), Ankara

Anonim, 2004. Türkiye Ulusal Ormancılık Programı (2004-2023). Çevre ve Orman Bakanlığı, APK Kurulu Başkanlığ1, 80 s., Ankara

Anonim, 2012. Orman Genel Müdürlüğü 2013-2017 Stratejik Planı, 2012. Ankara

Anonim, 2015. Batı Akdeniz Ormancılık Araştırma Enstitüsü Müdürlüğü, Ormancılık Örgütünün Yeniden Yap1landır1lması. Rapor, 2015

Anonim, 2017. Orman Genel Müdürlüğü 2017-2021 Stratejik Plan1, 2017. Ankara

Barlı, Ö., Türker, M. F., Ayyıldız, H. 2000. Türkiye Ormancılık Teşkilatının Örgüt Kültürünü Belirlemeye Yönelik Bir Çalışma, KTÜ Orman Fakültesi, Trabzon

Bensghir, T. K. 1996. Bilgi Teknolojileri ve Örgütsel Değişim. TODAİE Yayın No: 274, Ankara

Bingöl, İ. 1990. Geçmişten Günümüze Ormanlarımız ve Ormancılığımız. Cilt I, Ormancılık Eğitim ve Kültür Vakfi, Matbaa Teknisyenleri Basımevi, 144 s., İstanbul

Çağlar, Y. 1993. Ormancılığımızda Örgütlenme. Orman Bakanlığ1 Yayın No: 6, Seri: 13, Cilt: 2, s.424-428, Ankara

Daşdemir, İ. 1998. Devlet Orman İşletmelerinin Yönetsel ve Örgütsel Boyutlarının Belirlenmesi. DA Ormancı1ık Araştırma Müdürlüğü, Teknik Rapor: 3, 70 s., Erzurum

Daşdemir, İ. 1999. Çağdaş Ormancılık Anlayışı ve Örgüt Yapısı. ZKÜ Bartın Orman Fakültesi Dergisi, 1 (2): $25-47$

Daşdemir, İ. 2012. Türkiye Ormancılığında Araştırma-Uygulama İşbirliğinin Geliştirilmesi ve Araştırma Sonuçlarının Uygulamaya Aktarılması Üzerine Düşünceler. Kuruluşunun 60. Yılında Ormancılık Araştırma Enstitüleri: Dünü, Bugünü ve Geleceği Sempozyumu Çağrılı Bildirisi, Bildiriler Kitabı, s.117-129, 7-9 Kasım, Bolu

Daşdemir, İ. 2015. Ormancılık İşletme Ekonomisi (3. Bask1). Bartın Üniversitesi Yayın No: 10, Orman Fakültesi Yayın No: 6, ISBN 978-605-60882-8-5, 407 s., Bartın

Daşdemir, İ. 2016a. Orman Mühendisliğine Giriş Ders Notu. Bartın Üniversitesi Orman Fakültesi, Orman Mühendisliği Bölümü, DOI: 10.13140/RG.2.1.3828. 9043, 32 s., Bartın

Daşdemir, İ. 2016b. Türkiye Ormancılığında Çağdaş Yönetim Anlayışı ve Örgütlenme Modeli. Türkiye'nin Ormancılık Serüveni, Örgütlenmesi ve Ormancılıkta Kadının Yeri Paneli Kitabı, Türkiye Ormancılar Derneği Yayını, ISBN 978-605-64482-5-6, s.95-111, Ankara 
Daşdemir, İ. 2016c. Bilimsel Araştırma Yöntemleri. Nobel Akademik Yayıncılık ve Danışmanlık Tic. Ltd. Şti., Yayın No: 1536, ISBN 978-605-320-442-8, 210 s., Ankara

Eraslan, İ. 1989. Türkiye'de Ormancılık Öğretim ve Eğitim Kurumlarının Tarihsel Gelişimi. Ormancılık Eğitim ve Kültür Vakfı, Yayın No: 1, 157 s., İstanbul.

Eryılmaz, A.Y. 1985. Ormancılık Politikası Ders Notları. KTÜ Orman Fakültesi Ders Notları Yayın No: 96, Trabzon

Geray, A. U. 1982. Ormancılıkta Planlamanın Hazırlık Așamasında Çok Boyutlu Analizler (Akdeniz Bölgesi Örneği). İÜ, Orman Fakültesi Yayın No: 315, 108 s., İstanbul

Geray, A. U. 1989. Ormancılığın Çağdaş Çerçevesi. İÜ, Orman Fakültesi Dergisi, Seri: B, Cilt: 39, Say1 4, s.1727, İstanbul

Geray, A. U. 1993. Orman Kaynakları Yönetiminin Geliştirilmesi ve Sorunları. I. Ormancılık Şurası, Orman Bakanlığ1 Yayın No: 6, Seri: No: 13, Cilt: 3, s.137-149, Ankara

Gülen, İ., Özdönmez, M. 1996. Personel Yönetimi. İÜ Yayın No:3928, Fen Bilimleri Enstitüsü Yayın No: 7, Edebiyat Fakültesi Basımevi, İstanbul

Gümüş, C. 2014a. How to Adjust Forestry Education in
Accordance with the Forest Policy Process/Changes: Experience From Turkey. Sub-Regional Workshop on "Forest Policy and Institutions Development in Central Asia”, 4-7 February 2014, Trabzon, Turkey

Gümüș, C. 2014b. Osmanlıdan Günümüze Ormanc1lık Politikalarının Ormancılık Örgütlenmesi Üzerine Etkileri ve Güncel Sorunlar. II. Ulusal Akdeniz Orman ve Çevre Sempozyumu, 22-24 Ekim, s.477-489, Isparta

Kutluk, H. 1948. Türkiye Ormancılığı İle İlgili Tarihi Vesikalar 893-1339 (1487-1923). Osmanbey Matbaas1, İstanbul

Kutluk, H. 1967. Türkiye Ormancılığ İle İlgili Tarihi Vesikalar 102-1341(1787-1925). Ongun Kardeşler Matbaas1, Ankara

Orhunbilge, A.N. 2000. Örnekleme Yöntemleri ve Hipotez Testleri (Gözden Geçirilmiş ve Genişletilmiş İkinci Bask1). Avcıol Basım ve Yayın, 420 s., İstanbul

Özdönmez, M., İstanbullu, T., Akesen, A. 1989. Ormancılık Politikası. İÜ Orman Fakültesi Yayın No: 401, 301 s., İstanbul

Özdönmez, M., Akesen, A., Ekizoğlu, A. 1998. Ormancılık Yönetim Bilgisi Kitabı. İÜ Orman Fakültesi, Yayın No: 4157/457, 357 s., İstanbul

Yund, K. 1969. Türkiye Orman Umum Müdürleri Albümü. Hüsnütabiat Matbaası, 107 s., İstanbul 